\title{
LIGHTNING HAZARD SAFETY MEASURES AND AWARENESS IN BANGLADESH
}

\author{
A thesis submitted \\ to \\ Kent State University \\ in partial fulfillment of the requirements \\ for the degree of Master of Arts
}

By

Md. Sariful Islam

December 2018 
Thesis written by

Md. Sariful Islam

B.S., Mawlana Bhashani University of Science and Technology, 2014

M.A., Kent State University, 2018

Approved by

Thomas Schmidlin

$\underline{\text { Scott Sheridan }}$

James L. Blank , Advisor , Chair, Department of Geography , Dean, College of Arts and Sciences 


\section{TABLE OF CONTENTS}

TABLE OF CONTENTS iii

LIST OF FIGURES $\quad$ v

LIST OF TABLES _ vi

ACKNOWLEDGEMENTS vii

CHAPTER 1 - INTRODUCTION 1

CHAPTER 2 - LITERATURE REVIEW 4

Perceptions of Hazard $\quad 5$

Lightning as a Hazard 6

Hazard Awareness and Education $\quad 8$

Hazard Warning and Communication System 9

Lightning in Bangladesh $\quad 10$

$\begin{array}{ll}\text { CHAPTER } 3 \text { - METHODOLOGY } & 13\end{array}$

Data 13

Demographics of Survey Respondents $\quad 15$

$\begin{array}{ll}\text { Consent } & 15\end{array}$

Survey Data Collection $\quad 16$

Survey Data Entry $\quad 18$

$\begin{array}{ll}\text { Data Analysis } & 18\end{array}$

$\begin{array}{lr}\text { CHAPTER } 4 \text { - ANALYSIS AND RESULTS } & 20\end{array}$ 
Spatial Variation of Lightning Frequency

Seasonal Variation of Lightning in Bangladesh

Spatial Distribution of Lightning Deaths

Results of Survey Data

Agriculture and Lightning

CHAPTER 5 - DISCUSSION

Discussion

Recommendations

Conclusion

Limitations

REFERENCES

APPENDICES

62

A - Survey

62

B - Consent

66 


\section{LIST OF FIGURES}

Figure 1 Spatial Distribution of Population Density per Square Kilometers at

District Level

Figure 2 Selected Three Districts for Conducting Survey

Figure 3 Annual Spatial Variation of lightning Flash Density over Bangladesh

Between 1998 and 2013

Figure 4 Seasonal Variation in Lightning Flash rate Density over Bangladesh

Between 1998 to 2013

Figure 5 Lightning Fatality rate per million people per District over

Years 2011 to 2015

Figure 6 Relationship between the Total Population each District and the Lightning

Death rates per million Populations per District.

Figure7 Lightning Death rate per million People per Year per Square

Kilometers per District. 


\section{LIST OF TABLES}

Table $1 \quad$ Demographic Summary of the Survey Participants 28

Table 2 Overall Lightning Safety Knowledge and Perception Percentage 29

Table $3 \quad$ Male and Female Percentage of Responses and P-values for a 34

Test of Difference between Genders

Table 4 Education and Lightning Safety Knowledge and Perceptions 


\section{ACKNOWLEDGEMENTS}

There are so many people to thank for helping and supporting me throughout my thesis process. First, I would like to express my heartfelt gratitude, sincere appreciation and profound regards to my advisor Dr. Thomas Schmidlin, under whose systematic and careful supervision, and indefatigable guidance this study has been conducted. You are the person who has influenced me the most about first hand research. You are one of best professor as well as person I have ever met in my life. I feel proud to be your student.

I would also like to thank my two additional committee members, Dr. Scott Sheridan and Dr. Jacqueline Curtis. Thank you both for your invaluable suggestions and cordial co-operation to accomplish the study. Without your suggestions and guidance, this thesis would not have been possible.

I wish to render special thanks to Md. Rafiqul Islam, $\mathrm{PhD}$ candidate, Department of Geography at Kent State, for his meaningful support and cordial help throughout the study. I am sincerely thankful to my friend, Mizanur Rahman who has helped me conducting the questionnaire survey in Bangladesh. I would also like to render special thanks to Naushaba Khan Rasha who has supported and helped me throughout my study. Thank you Rasha for being my side always.

I would also like to thank Department of Geography at Kent State University for all the support throughout the study. The faculty, staff and students really made my stay in Kent one I 
will always remember. To the graduate students, thank you all for your companionship throughout my graduate life at Kent State University.

Finally, I will also have to express my hearted gratitude to my parents, family members and friends for their encouragements and supports to complete this thesis fruitfully. Thank you all for being there for me and supporting me. 


\section{CHAPTER 1}

\section{Introduction}

Bangladesh is located in South Asia between 20 $34^{\prime}$ to $26^{\circ} 38^{\prime}$ north latitude and $88^{\circ} 01^{\prime}$ to $92^{\circ} 42^{\prime}$ east longitude with an area of $147,570 \mathrm{~km}^{2}$. Bangladesh has a population of about 152.25 million based on population census 2012, making it one of the most densely populated countries of the world. The average population density at district level ranges from 87 to 8227 persons per square kilometer.

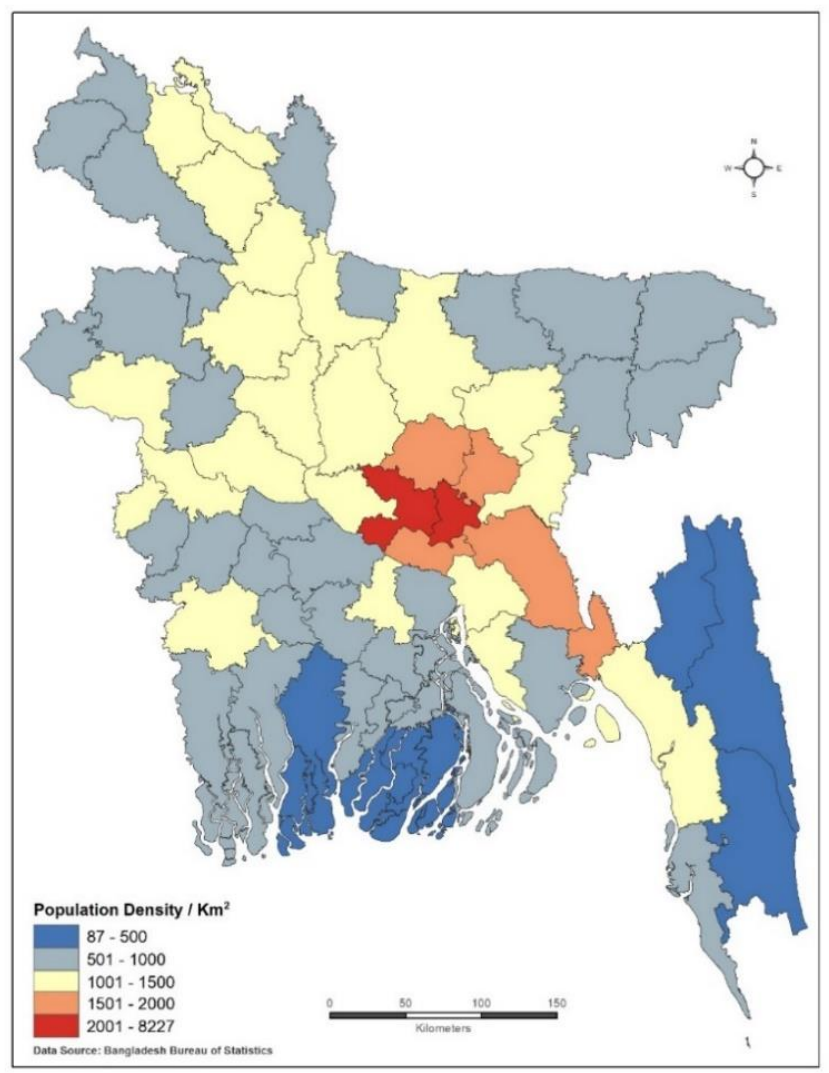

Figure 1 - Spatial distribution of population density per square kilometer at district level (Data Source: Population Census - 2011, Bangladesh Bureau of Statistics). 
More than $75 \%$ of the population lives in rural areas. Urbanization has, however, been rapid in the last few decades. Of the total area of Bangladesh, agricultural land makes up $65 \%$ of its geographic surface, forestlands account for almost $17 \%$, while urban areas are $8 \%$ of the area (BBS, 2015). The highest population densities are in the capital city Dhaka and its surrounding districts. The lowest population densities are found to be in the hilly areas and at some coastal districts of Bangladesh.

Bangladesh is prone to several types of natural hazards. Lightning is among the most widespread and deadly hazards. Bangladesh is giving more attention recently to the lightning hazard. Lightning was widely ignored previously but it appeared recently that the loss of lives and property due to lightning is increasing, so the government is giving more attention to minimize the losses due to lightning. The Bangladesh government has recently declared lightning as a natural disaster (Islam, 2016). Some studies show that the lightning death rates are higher in developing countries than developed countries (Holle, 2008).

Bangladesh has among the highest death rates in the world from hazards like lightning (Schmidlin, 2009). I have chosen Bangladesh as my research area as the recent study shows that only a limited amount of research has been conducted on the people's perception of the lightning hazard. As it is one of the lightning-prone countries of the world, there may be some key factors causing this large death toll due to lightning. It may be useful to study the reasons behind these large death tolls in Bangladesh due to lightning. There may be some misconceptions and myths about lightning, there may be inadequate safety measures or people may have a lack of adequate training and awareness about lightning that needs to be studied to minimize the death tolls and loss of property in Bangladesh. The goal is to look at the people's perception of lightning and safety measures taken by the peoples to keep themselves safe during the lightning occurrence. 
As a developing country, death rates are higher in Bangladesh than most of the developed countries in the world. Previous study showed that lack of awareness among the people and ignorance of the safety rules is one of the main reasons for the higher rates of deaths and injuries of the people in Bangladesh (Gomes et al., 2006a). The impacts of lightning vary greatly between more developed countries and lesser-developed areas. Lightning safety education and awareness play a key role in minimizing the death tolls around the world. A significant education and awareness have been triggered to minimize the death tolls in the developed countries like United States (Cooper and Holle, 2012). My main research goal is to address why the death rates are higher in Bangladesh than the developed countries of the world. This research will answer the following questions:

1. What are the geographic variations in lightning frequency and deaths due to lightning?

2. What are the perceptions about lightning hazards in Bangladesh?

3. What are the safety measures taken by the people in Bangladesh to be safe from lightning accidents?

Three types of data were used to answer the questions above. Lightning deaths data and lightning strike data have been used to look at the different geographical areas of Bangladesh that are prone to lightning. A death rate map was produced in district level to look at the different level of deaths rate. Three districts were selected from the death rate map having highest, moderate and lowest death rates to conduct the questionnaire survey. The responses of the people will answer the questions related to their perception and safety measures taken. 


\section{CHAPTER 2}

\section{Literature Review}

A natural hazard can be defined as natural events that threaten lives, property and other assets (FEMA, ND). According to the United Nations, a hazard can be defined as a potentially damaging physical event, phenomenon or human activity that may cause the loss of life or injury, property damage, social and economic disruption or environmental degradation (UNISDR, 2004).

A hazard can be viewed as

$$
\text { Hazard = f (Risk X Vulnerability X Exposure X Response) }
$$

The risk is the probability that a hazard will cause deaths or injuries, loss of property or damage to the environment. The vulnerability is an essential concept in hazard research and can be defined as the likelihood that an individual or group will be exposed to and adversely affected by a hazard (Cutter, 1993). Some major factors influence the vulnerability of the people to a hazard event. These factors include lack of access to resources, lack of political power and representation, beliefs and customs, type and density of infrastructure (Cutter et al., 2003). Hazard exposure can be defined as the state when individual or group of people are at imminent risk of danger. The response can be defined as the action taken by the people before, during and after a disaster in order to save lives and property and meet the basic needs of the affected people of a disaster event. 


\section{Perceptions of Hazard}

Interest in people's perception in hazard research started to grow when Gilbert F. White published his influential dissertation entitled "Human adjustment to floods" (White, 1945). Later professor White with his students and colleagues, including Robert Kates and Ian Burton, became some of the most eminent scholars of the field of natural hazard research. Perception has a role in explaining the risk and uncertainty by which societies and individuals interact with natural hazards. In natural hazards research, perception studies play a central role (Burton et al., 1993). The perceptions of a particular hazard vary among individuals and societies and it can be accounted for by the combination of the way that natural hazards are perceived, the nature of personal encounters with that hazard and factors of individual personalities (Kates, 1971). People's perception has been studied in different types of hazards including cyclone, flood, fire, earthquake, volcanic eruption, lightning, etc. (Johnston et al., 1999; Jackson, 1981; Glade et al., 2006; Grothmann and Reusswig, 2006). Many hazard researchers have used people’s perception to study lightning hazard (Greening and Dollinger, 1992; Jayaratne and Gomes, 2012; Spengler et al. 2002; Keul, 2012). Some studies have combined both GIS and public perceptions to research hazard issues (Hagemeier and Wagner, 2009; Brennan et al. 2016).

Perceptions of hazard vary from person to person, age level, education level, from men to women, and based on experience with that particular hazard etc. A study by Bosscharrt et al. (2013) showed that people with a higher perception of environmental and geographical phenomena also have high perceptions of risk. Logical thinking based on correct knowledge of that particular hazard influences the perceptions of the risk among the people. Past experience of a hazardous event is an important factor that influences people's perception of hazards. Previous experience of any hazard event makes them more concerned and worried about the reoccurrence 
of risk. Ultimately, their perceptions are different from the people who are not experienced to that particular hazard event. Weinstein (1989) showed that experience has effects on the perception of seriousness and controllability and people take the precautions when they believe that is appropriate for the particular hazard from their past experience. Perceptions may vary from men to women. In a case study of earthquake risk in Taiwan, Kung and Chen (2012) showed that women felt more fearful, worried, concerned and threatened to earthquake risk than the men. It may indicate that women are more sensitive to risks than men. Differences in perception may not only be due to the physical and biological differences but it may have other social and cultural factors too.

\section{Lightning as a hazard}

Lightning is the spark of electricity between clouds, or between clouds and the ground. Lightning occurs when two clouds with different electric charge content come near each other. There are different types of lightning and the most common types include intra-cloud, cloud-tocloud, cloud to ground and cloud to air. The most common type of lightning is the intra-cloud lightning. Lightning is unpredictable in nature. Lightning is one of the dangerous natural hazards due to its unpredictability and frequency of strikes (Holle et al. 1999). Lightning is one of the deadliest hazards. For example, in the USA, there are more deaths due to lightning than any other natural disaster other than floods and heat (Holle, 1999; Lopez et al. 1993).

Natural hazards occur all over the world but the damage due to these natural phenomena are higher in the developing countries. This is due to the locations of these countries and triggered by different kinds of socio-economic factors (Alcántara-Ayala, 2002). Every year 
thousands of people are killed or injured by lightning throughout the world. About 24,000 deaths and 240,000 injuries are recorded worldwide from lightning annually (Holle, 2008). Many researchers have shown the difference in the number of casualties due to lightning between developed and developing countries. In developing countries, the population-weighted rate of lightning fatalities is steady or slowly decreasing due to urbanization and the availability of lightning safe buildings. However, the absolute number of the lightning vulnerable people involved in labor-intensive agriculture who live and work in unsafe dwellings are increasing and ultimately the total number of casualties may grow due to such socio-economic factors (Holle, 2016). Different socio-economic factors play a vital role in the number of causalities by lightning. Socio-economic factors include literacy rate, age, gender, occupation, etc. Geographic factors are also important in terms of the lightning deaths and injuries. For example, rural areas accounted for $51 \%$ of the total lightning deaths and injuries despite having less population per square mile. A majority of the injuries and deaths occur to people working in the field (Zhang et al. 2011). The most common agricultural location where most people are killed due to lightning in the world other than in the United States is in paddy fields (Holle, 2016).

We cannot stop lightning but we can minimize the potential damages. Lightning hazard can be mitigated in many ways. Insurance can play a potentially valuable role in encouraging loss reduction measures against natural hazards and for providing recovery funds to disaster victims (Kunreuther et al. 1996). The challenges faced by developed countries and developing countries are different. The challenges in developing countries are poverty, illiteracy, disorganized or uncoordinated nature of various institutions that directly responsible for lightning hazard mitigation, lack of modern equipment for accurate weather forecasting and lack of proper policies and standards (Mary et al, 2014). In developed countries like USA, the 
challenges of mitigating lightning fatalities include the willingness to cancel or postpone activities, the ability to be aware of an approaching or developing storm, the vulnerability of actual activity and the ability to get to a safe place quickly (Jensenius, 2016).

\section{Hazard Awareness and Education}

Awareness about any hazard can play a vital role in minimizing the effects of a hazardous event. The loss from disaster events is increasing globally. Human dimensions, specifically our awareness and decision-making behavior, are powerful explanatory factors of increasing disaster-losses (Haque and Burton, 2005). All people can contribute to minimize the loss due to disasters. Even children can play a role in minimizing the potentiality of loss from a hazardous event. Children are the assets and leaders of the future, can learn to protect themselves and their environment in the future through a global culture of mitigation (Izadkhah and Hosseini, 2005). Educating children about hazards and mitigation strategies will help to create a safe local habitat for children to develop to their full potential, with the knowledge that if disaster strikes, they and their community are well prepared. However, in order to achieve this objective, we must ensure that learning is fun for them (Clerveaux and Spence, 2009). The lack of constructive and integrative dialogue among the different levels of stakeholders can hinder the sustainable disaster risk reduction (Mercer, 2010; Gaillard, 2010). Research shows that participatory mapping seems to be a good tool to enhance awareness about any hazards among the youth (Gaillard and Pangilinan, 2010).

Research on lightning hazard education has been neglected. Lightning education should emphasize proactive planning. A proactive plan involves (1) recognizing the development of a 
storm that may produce lightning, (2) noting the start of the lightning threat from the storm, and (3) making a plan for reaching the shelter at all stages of the outdoor activity (Holle et al. 1995). Literacy rate among the people plays a role in terms of deaths and casualties. The demographic factors like population density, literacy rate, and urbanization have direct impacts on lightning casualties (Gomes and Kadir, 2011). As lightning is a hazard that is unpredictable in nature, people may not follow precautions in all lightning events. Lengyel et al. (2005) showed that $42 \%$ of the deaths by lightning are caused due to lack of proper knowledge of awareness about this hazard. Raising awareness can minimize the number of deaths (Gomes et al., 2006b). Research shows that sometimes safe shelters were available close to the victims but they did not act soon to get the safety before the storm struck (Jensenius, 2016). Education is the powerful key and it needs to be communicated effectively to reduce the death tolls due to lightning strikes (Roeder et al., 2011). Lightning deaths and injuries can be minimized by raising awareness and educating people. An effort to increase awareness, educating people about lightning safety measures can lower the death rates (Jensenius and Franklin, 2014).

\section{Hazard Warning and Communication System}

An effective communication to warn people of an impending hazard and proper actions to take can minimize the losses. Effective communication requires that the public is motivated to learn the information and that the information is taught effectively (Roeder et al. 2011). Information and Communication Technologies (ICT) and various media can play a major role in terms of communication. The use of ICT in the form of information dissemination during disasters can reduce the impacts of those events. Members of communities derive immediate benefits and establish emergency practices that prepare for the future preparation for any 
disasters (Shklovski et al., 2008 and Samarajiva, 2005). The dissemination of any hazard events map (for example floods) using the internet can play a vital role to circulate the information of that hazard/disaster event to the public (Hagemeier and Wagner, 2009). Though still, it's necessary to circulate hardcopies of the map to people who are not connected with internet. Computer sciences and communication resources play an increasingly important role in our understanding of hazardous events and are all dependent on communications links and computer technology to be timely and effective.

Early Warning System (EWS) can play a vital role in saving lives and property. It is selfevident that a timely early warning can minimize the potential loss and is a basic component of any disaster risk reduction strategy. Many researchers have shown that if EWS properly works and is timely acted upon then lives and property will be saved (Blaikie et al. 2014). It is important to place increased emphasis on mitigation, preparedness and early warning to minimize the loss of lives and property from every hazard event (Wilhite, 2000). Forecasting system is integrated part of any hazard/disaster event. Effective forecasting can minimize the loss of lives and property. The information should be clear and simple as possible with instructions on what to do (Brilly and Polic, 2005).

\section{Lightning in Bangladesh}

Bangladesh is one of the most lightning hazard-prone countries of the world. Death rates are increasing in recent years causing the government to declare lightning as a natural disaster in 2016. A recent study by Dewan et al. (2017) has shown that each year on an average 114 people have been killed by lightning in Bangladesh over the period from 1990-2016. Socio-economic 
factors play a key role in terms of death tolls. Lack of awareness of the people and ignorance of the safety rules is one of the main reasons for the deaths and injuries of the people in Bangladesh (Gomes et al., 2006a).

Lightning occurs in Bangladesh mostly in the months of May and June. Most events occurred during the afternoon when lightning is to be expected in a tropical or monsoon environment like Bangladesh. As most of the deaths in the developing countries take place in the agricultural fields, properly designed lightning safety structures near the agricultural fields are necessary to minimize the death tolls due to lightning in the developing countries like Bangladesh (Holle, 2016). The majority of lightning accident occurred between early morning and early evening. Pre-monsoon season had the most number of lightning fatalities (Dewan et al. 2017). Within two days (12 and 13) of May 2016, 64 people were killed by lightning in Bangladesh. The majority ( $61 \%$ of total) of the fatalities occurred in the agricultural field while farmers were working at their field (Holle and Islam, 2017)

Lightning awareness programs in Bangladesh were started in 2004. Initially, these programs were conducted only for the school teacher. The main goal of these programs was to train the school teacher so that they will disseminate this knowledge among the students, guardians and local community. However, the lectures and presentations are not effective in the rural areas due to low literacy rate (Gomes et al, 2006b).

Therefore, to know about the lightning hazard situation in Bangladesh, this study is going to assess people's perception of lightning. The main goal of this master's thesis is to determine the main reasons behind a large number of deaths in Bangladesh due to lightning. At the end of the study, this research will come up with some key recommendations to be safe from lightning. As a result, this research will be able to help at the government and private level of decision 
making for proper planning to minimize the loss of lives and property due to lightning in Bangladesh. 


\section{CHAPTER 3}

\section{Methodology}

\section{Data}

Lightning deaths data from 2011 - 2015 were collected from an NGO (Non-Government Organization) named Disaster Forum working in Bangladesh. Population data were collected from Bangladesh Bureau of Statistics at the district level to calculate the rate of deaths per millions of people. Using the death rates at the district level, a map of death rates of lightning has been produced that has been as the basis for conducting the survey.

Lightning strike data were collected from NASA lightning datasets (Albrecht, et al., 2016a). These data are freely available for public use. This dataset is of sixteen years of data from 1998 to 2013. Lightning Imaging Sensor (LIS) of Tropical Rainfall Measurement Mission (TRMM) has collected this data. This dataset has been used to look at the geographical variations of lightning strikes over Bangladesh.

The final source of data has been collected by conducting a questionnaire survey in three districts of Bangladesh. A detailed questionnaire survey was conducted to examine lightning perception and safety measures. Many researchers have used questionnaire survey for looking at the people's hazard perception (Jayaratne and Gomes, 2012; Takao et al. 2004). The questions in the survey include both open ended and close-ended questions. Most of the survey questions were close-ended questions but some of the questions were open-ended questions. The study 
areas were chosen to represent different geographic regions of high, moderate and low death risks. The three districts out of sixty-four districts in Bangladesh include Kishorganj, Sunamganj and Gazipur district.

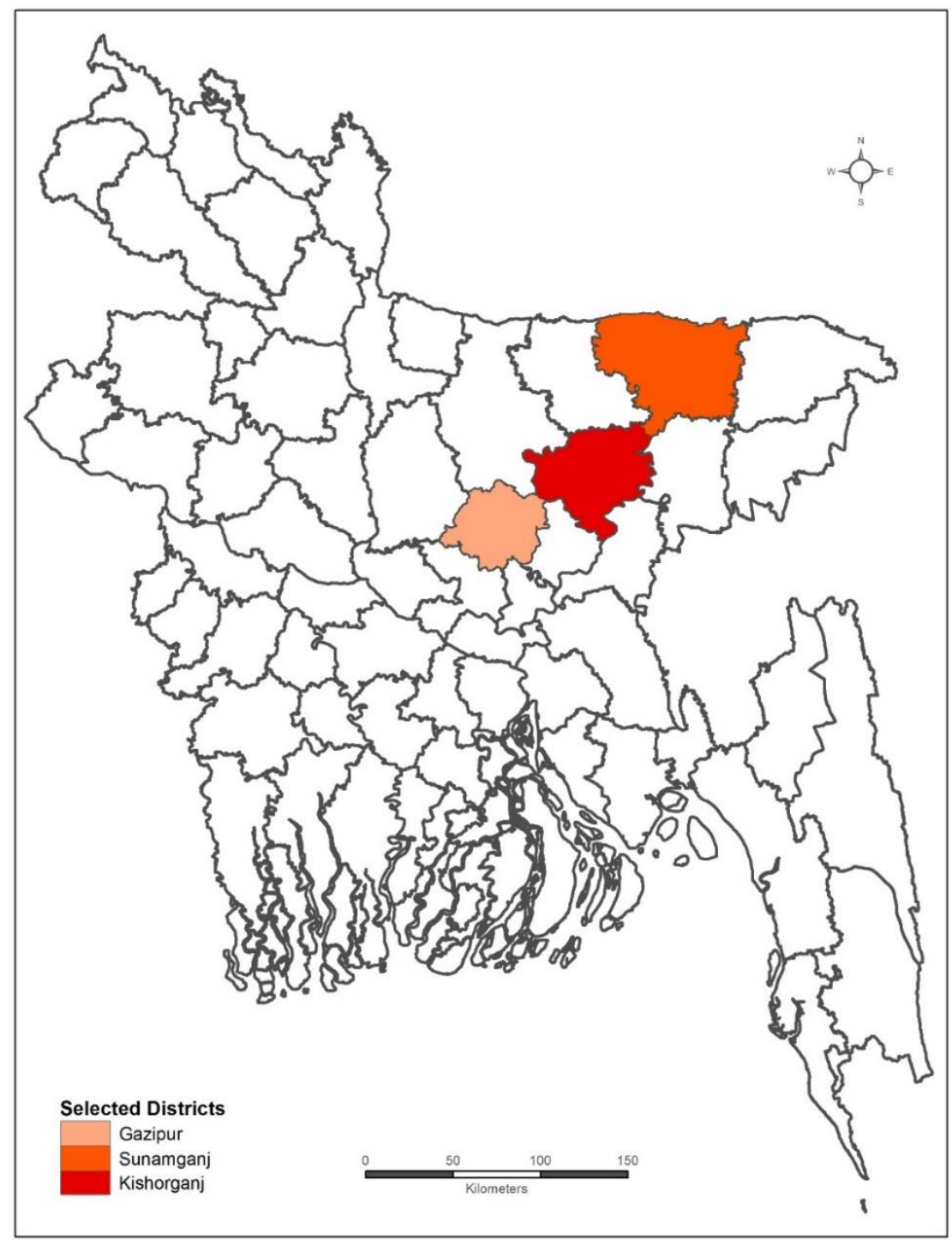

Figure 2 -Map showing selected three districts (Kishorganj, Sunamganj and Gazipur) for conducting survey having high, moderate and low death rates per million populations.

The questions of the survey collected information about the demographics of the respondents and the perceptions of the respondents about the lightning hazard in Bangladesh. Different kinds of questions include their awareness, safety knowledge, precautionary measures before, during and 
after lightning strikes. To avoid question wording problems, at least 10 survey questionnaires were distributed before conducting the survey in Bangladesh. A mixture of simple random sampling and cluster sampling were used to select the respondents. Two places were chosen from each district to balance the respondent's variation. As a majority of the educated people live in the city area, a place in each district was chosen in the urban area and other place was chosen in the rural area to make sure that all types of people having different occupations and education levels can express their opinions about lightning in Bangladesh. The places were chosen based on raw data of lightning deaths focusing on the places where the most people are being killed due to lightning on that particular district.

\section{Demographics of Survey Respondents}

Participants of this study were above eighteen years old. Both males and females of different occupation and different education level were chosen to look at the variation of perceptions at different gender and education levels. It helps to look at the variations of perceptions among different groups of people living in a same area. The majority of populations of this survey had no higher education. A large number of the respondents were housewife and farmer.

\section{Consent}

A consent form was given to educated respondents or read by the survey administrators for the people who do not know how to read before starting the formal survey to allow the people for fair disclosure of the survey process as well as inform the respondents about their rights to 
participate or not participate in the survey, the purpose of the survey, the possible risks and benefits from this survey and the privacy and confidentiality of the questionnaire survey. The consent form was also offered for further review to the participants by providing the contact information of the investigators of this survey research. The consent form of this study can be found in Appendix B.

\section{Survey Data Collection}

Survey questions include some basic demographic questions including their gender, age, occupation, education level, multiple-choice questions, and some open ended questions about the perceptions of lightning in Bangladesh. The sample survey can be found in Appendix A. The variables in questionnaire survey include:

- Age

- Gender

- Occupation

- Education level

- Which season does lightning occur in your locality?

- Has frequency of lightning changed in recent years?

- Have lightning death rates changed in recent years?

- Are you in danger of being struck by lightning while outdoors?

- Did you lose anything due to lightning strikes?

- Was someone you know injured due to lightning strikes? 
- Is there any siren, sign or announcement take place during lightning in your locality?

- Is there any sign, siren or announcement at your workplace while working outside of home?

- How do you know lightning is nearby?

- Do you follow weather forecasting on TV/ radio?

- Did you get any lightning safety precaution/ training from your local authority?

- Do you feel lightning as dangerous?

- Do you take any shelter if you hear sound of thunder suddenly?

- Are you already in danger while outdoors hearing thunder?

- What are the safe places during thunderstorm?

- How long do you usually wait at a safe place after the last apparent lightning flash?

- Do you think that strike victims do not carry an electrical charge and may be safely touched?

- Do you look at weather forecast before planning to be outdoors?

- How many people are being killed each year due to lightning in Bangladesh?

- From where do you know about the lightning deaths?

- What activities should not be done during lightning?

- What are the reasons behind struck by lightning?

- What kind of safety measures do you take when lightning occurs?

- What may happen to a person struck by lightning? 


\section{Survey Data Entry}

After collecting survey data, all surveys eligible were entered into an Excel Spreadsheet for statistical analysis and to make tables and graphs. Only three survey responses were omitted due to missing gender of the respondents. Responses were coded by assigning a unique number for each response. For the open-ended questions, there were different types of responses. In terms of open-ended responses, the general themes and trends of the answer types were analyzed. For the short answer questions, the responses were categorized assigning a numerical code for each category and then coded them for further statistical analysis.

\section{Data Analysis}

The lightning strikes and deaths that have been collected from two different sources have been used to make some maps to show the geographical variations of lightning strikes and deaths over Bangladesh. The data format of lightning strikes was in NetCDF. First, it was converted and then exported to ArcGIS. ArcGIS 10.5.1 has been used to produce the map. The data was in grid cell format. Bilinear Interpolation method was used to make the grid cell merge with its neighboring cells.

The lightning deaths data from 2011 to 2015 was at district level having the number of people who died each year in each district. The average number of deaths per year per district was calculated first. Population data by district was collected from Bangladesh Bureau of Statistics (BBS). Using this population and deaths rate per year, death rate per year per million populations in each district were calculated. Using this rate, different types of choropleth map at district level has been produced. 
After coding the survey responses, the frequencies and percentage of the response for each question were calculated. For looking at the relationship between different subgroup, cross tabulation was used. Cross-tabulations provide a way of analyzing and comparing the results for one or more variables with the results of another. Cross tabulation has been used to test for significant difference among different demographic factors such as gender and education level.

Chi-squared tests were performed to analyze the perception variation between male and female. A chi-square analysis is used to investigate whether distributions of categorical variables differ from one another. The chi-squared analysis provides a probability (p) value that indicates that group difference occurred by chance alone. $\mathrm{P}$ values are significant when it will be 0.05 or less. If the result of chi-square test had cells with expected value less than five, the test was not utilized. If the $\mathrm{P}$ value of chi-square test was less than 0.05 , has been indicated by underlined and bold and If the $\mathrm{P}$ value was less than 0.10 , has been indicated that by bold type. 


\section{CHAPTER 4}

\section{Analysis and Results}

\section{Spatial Variation of Lightning Frequency}

Figure 3 shows the spatial variation of lightning strikes in Bangladesh. Analysis of spatial variation of lightning density suggests that the northern and northeastern part of Bangladesh have the highest value of lightning flash rate density. This map also suggests that higher latitude have high flash rates. The districts in the high latitudes include Sherpur, Jamalpur, Sunamganj, Netrokona, Kishorganj etc. A previous study also has shown that there is a strong relationship between lightning strikes and latitude. A study by Kandalgaonkar et al (2005) showed that lightning strikes rate increase with latitude in the Indian subcontinent. A higher latitude has higher rates of lightning strike frequency and the areas in the lower latitude has lower rates of lightning strikes. The eastern part of the country has high to moderate rates of flash per year. The districts include Kishorganj, Moulabibazar, Habiganj etc. The hill tracts of Bangladesh and the coastal areas close to Bay of Bengal are experiencing lowest rates of lightning flash. The coastal districts are Khulna, Patuakhali, Bhola, Noakhali, Jhalokhati Coxsbazar etc. The coastal areas and the hill tracts are located in the southern part of Bangladesh and they are in the lower latitude of the northern hemisphere.

Bangladesh is home to some lightning hotspots in the world. Albrecht et al (2016a) has

published a list of 500 lightning hotspots around the world based in $0.1 \times 0.1$-degree resolution 
using NASA's TRMM LIS very high resolution lightning annual climatology data from 1998 to 2013. There are some lightning hotspots located in Bangladesh. The place having highest flash rate density among those hotspots located in Bangladesh named Sherpur district (a district located in the northern most border of Bangladesh) with $82.95\left(\mathrm{fl} \mathrm{km}^{-2} \mathrm{y}^{-1}\right)$. This study has also found that the hotspots are located in the northern districts including Sherpur, Sunamganj and Netrokona. This part of Bangladesh experiences the majority number of lightning deaths that has been found after analyzing the lightning death data from 2011 to 2015 .

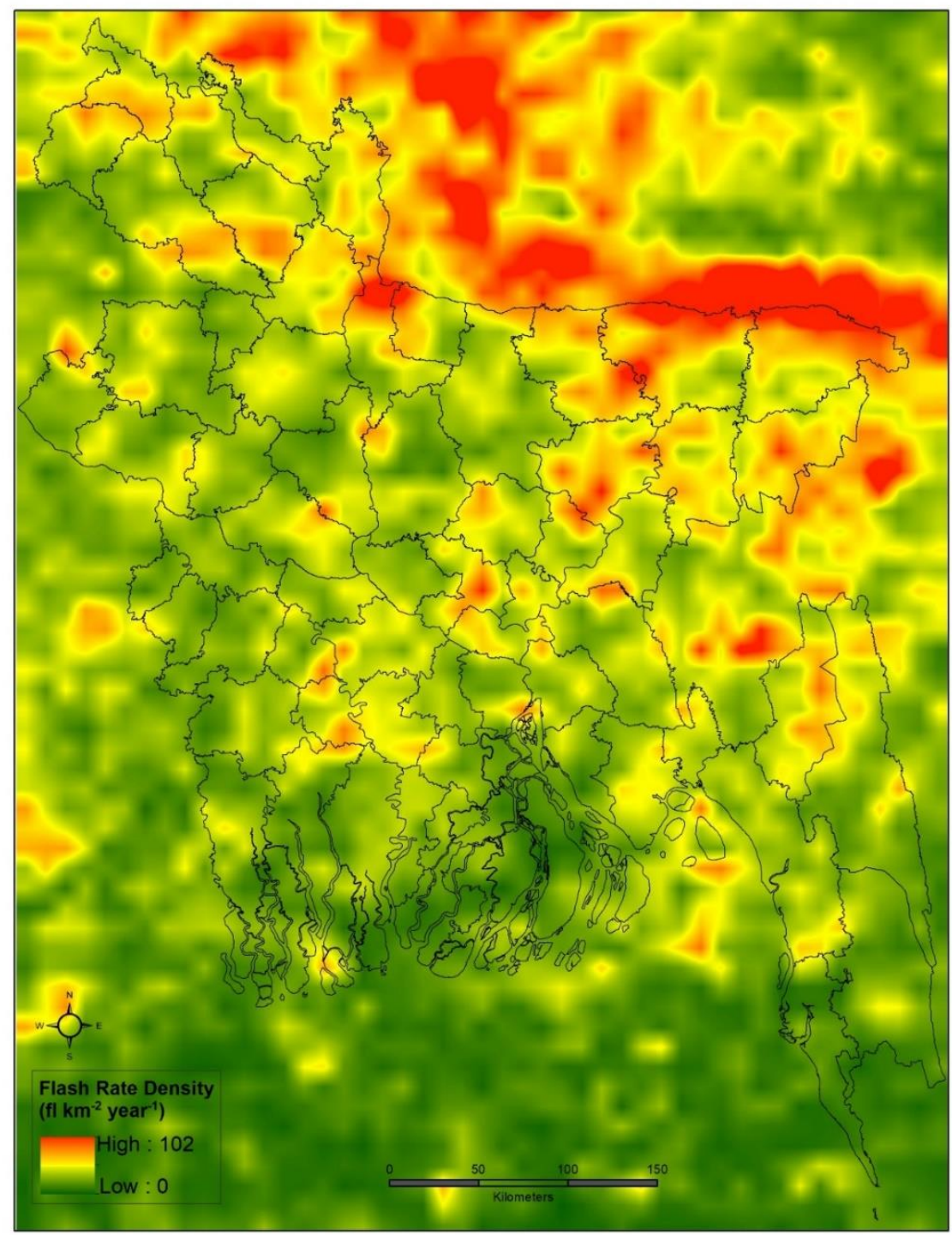

Figure 3 - Spatial variation of lightning flash density over Bangladesh between 1998 and 2013. 
Seasonal variation of lightning in Bangladesh

The seasonal variation of lightning flashes in Bangladesh from 1998 to 2013 has been shown in Figure 4. The highest rate of lightning strikes during the pre-monsoon season over Bangladesh (Fig. 4b). Figure 4a depicts the lightning flash density during winter season over the sixteen years. The flash rate density during winter season ranges from a minimum zero to a maximum $0.034\left(\mathrm{fl} \mathrm{km} \mathrm{km}^{-2} \mathrm{~d}^{-1}\right.$. During winter season, the flash rate density is highest in the northeastern part of Bangladesh. In particular, the districts like Sylhet and Sunamganj is experiencing the highest number of flashes per square kilometers per day during this season. The northwestern and southeastern part of Bangladesh experience the lowest rates of flash in Bangladesh in winter season. Bangladesh experiences the lowest rate of lightning flash in this season. Tibetan Plateau acts as a heat sink which contributes to the development of strong local convection in and around the Indian region, resulting in low lightning activity during the winter season in this region (Ramesh Kumar and Kamra, 2012).

Figure $4 \mathrm{~b}$ is showing the spatial variation of lightning flash rates over Bangladesh during pre-monsoon season between 1998 to 2013. This season experiences the highest rate of flash density among all seasons. Previous research also has found that this season is experiencing the highest rate of lightning in this region (Dewan et. al., 2017b; Ranalkar \& Chaudhari, 2009). The flash rate density during this season ranges from a minimum $0.0023\left(\mathrm{fl} \mathrm{km} \mathrm{km}^{-2} \mathrm{~d}^{-1}\right.$ to a maximum $0.4927\left(\mathrm{fl} \mathrm{km} \mathrm{km}^{-2}\right)$. The flash rate density map of this season is indicating that the rate increases with latitude. It is observed that the northern and northeastern parts of Bangladesh experience highest rate of lightning flash during pre-monsoon season. The districts experiencing the highest rates of lightning during pre-monsoon season includes Sylhet, Sunamganj, Netrokona, Sherpur etc. The southern part of Bangladesh (coastal area) experience the lowest rate of flash density 
during this season. The central part of Bangladesh experiences the medium rates of lightning flash density during the pre-monsoon season.

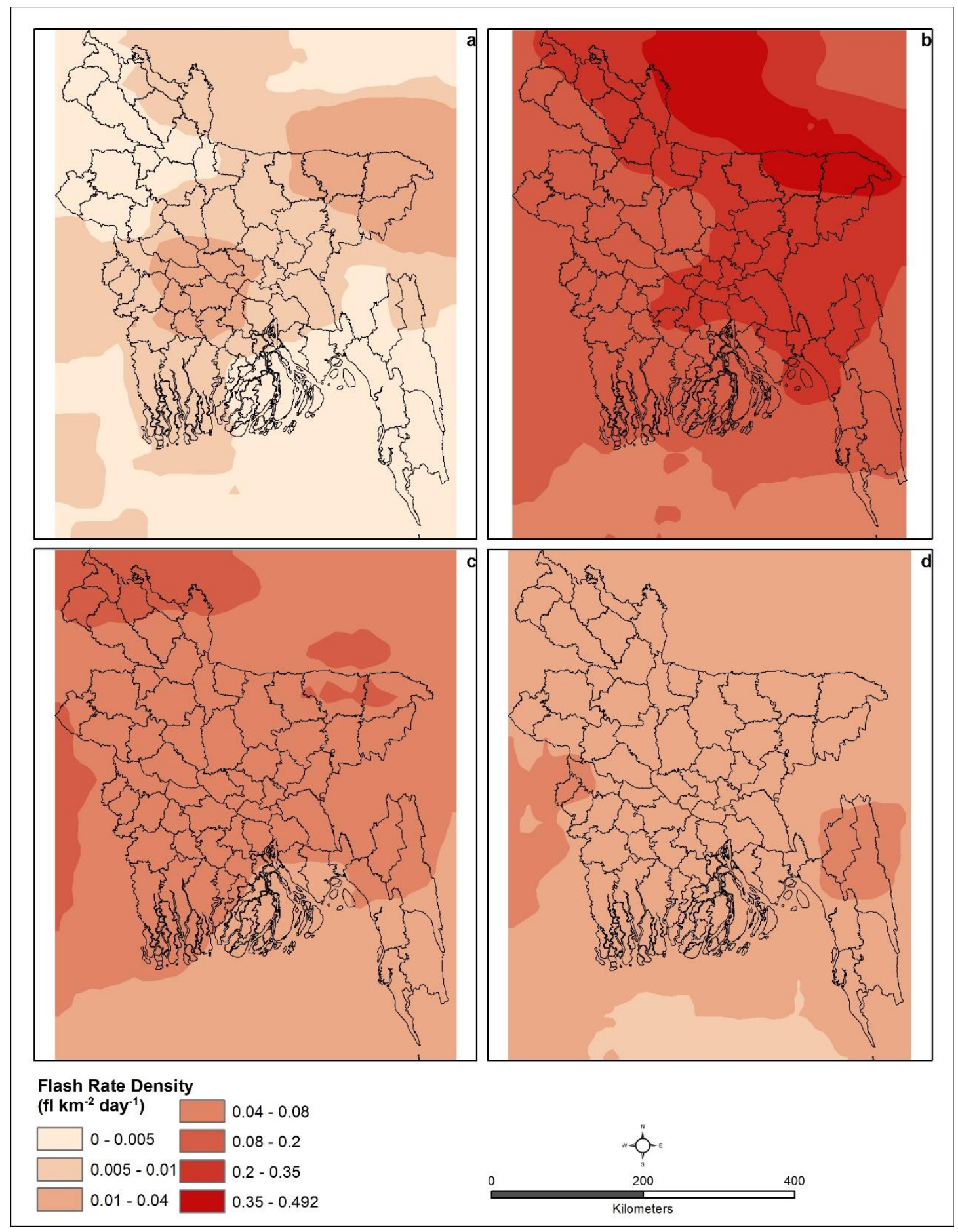

Figure 4 - Seasonal variation in lightning flash rate density over Bangladesh between 1998 to 2013: a winter (December - February), b pre-monsoon (March - May), c monsoon (June - August), and d post-monsoon (September - November). 
Figure $4 \mathrm{c}$ represents the spatial variation of lightning strikes rate over Bangladesh during monsoon. This season experiences the second highest number of lightning in Bangladesh after pre-monsoon season. The lightning flash rate density during this season ranges from 0.005 (fl $\left.\mathrm{km}^{-2} \mathrm{~d}^{-1}\right)$ to a maximum $0.108\left(\mathrm{fl} \mathrm{km}^{-2} \mathrm{~d}^{-1}\right)$. The longitudinal expansion of lightning intensity over Bangladesh was observed from pre-monsoon to monsoon season during these sixteen years of time. The flash rate density map of monsoon season suggests that the northwestern part of Bangladesh experiences the highest rates of flash density and the western, northern and northeastern part experience the highest to moderate rate of lightning flash during this season. The coastal area of Bangladesh experience the lowest rates of lightning strikes during monsoon season.

In post-monsoon season (Fig 4d), the spatial pattern of lightning flash density is different than the rest of the seasons. During this season, the southeastern part (hilly area) experiences the highest rates of lightning strikes. The districts include Rangamati and Khagrachari in the hilly areas of Bangladesh. The flash rate density during this season ranges from a lowest 0.0005 (fl $\left.\mathrm{km}^{-2} \mathrm{~d}^{-1}\right)$ to a highest $0.0507\left(\mathrm{fl} \mathrm{km} \mathrm{km}^{-2} \mathrm{~d}^{-1}\right)$. From winter to post-monsoon season, there are geographical variation of lightning strikes intensity over Bangladesh. A recent study by Dowdy (2016) has found that ENSO has the strongest relationship with lightning activity during each individual season in the tropical regions. A measure of ENSO variability is significantly correlated with local lightning activity at $53 \%$ of locations for one or more seasons throughout the year. Variations in atmospheric parameters commonly associated with thunderstorm activity are found to provide a possible explanation for the variations in lightning activity. 


\section{Spatial distribution of lightning deaths}

Figure 5 shows the spatial variation of lightning deaths over different geographical locations ranging from a lowest 0.19 (per million people per year) to the highest 6.68 (per million people per year). The highest rate of deaths is found in the districts like Kishorganj, Chapai Nawabganj, Sherpur etc. The lowest rate of deaths is found in the coastal area and the central including the capital city Dhaka.

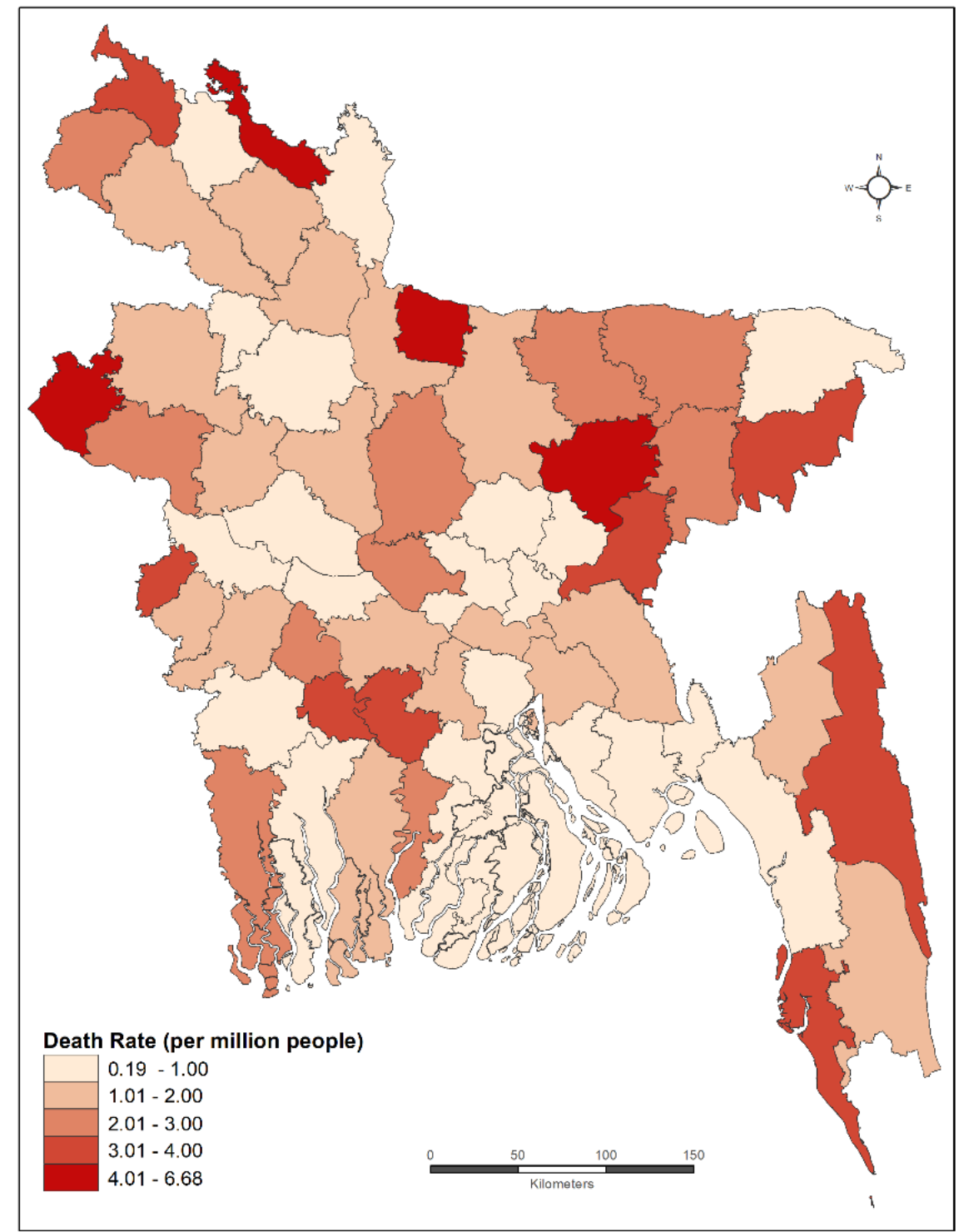

Figure 5 - Lightning fatality rate per million people per district over years 2011 to 2015. 
Fig. 6 shows total population and the lightning death rates per million populations. In number, Dhaka district has the highest population and the population density but in terms of the lightning death rates, this district is in the lowest of the list. Different factors may contribute to the lowest rates of death in Dhaka district including education, types of housing, occupation etc.

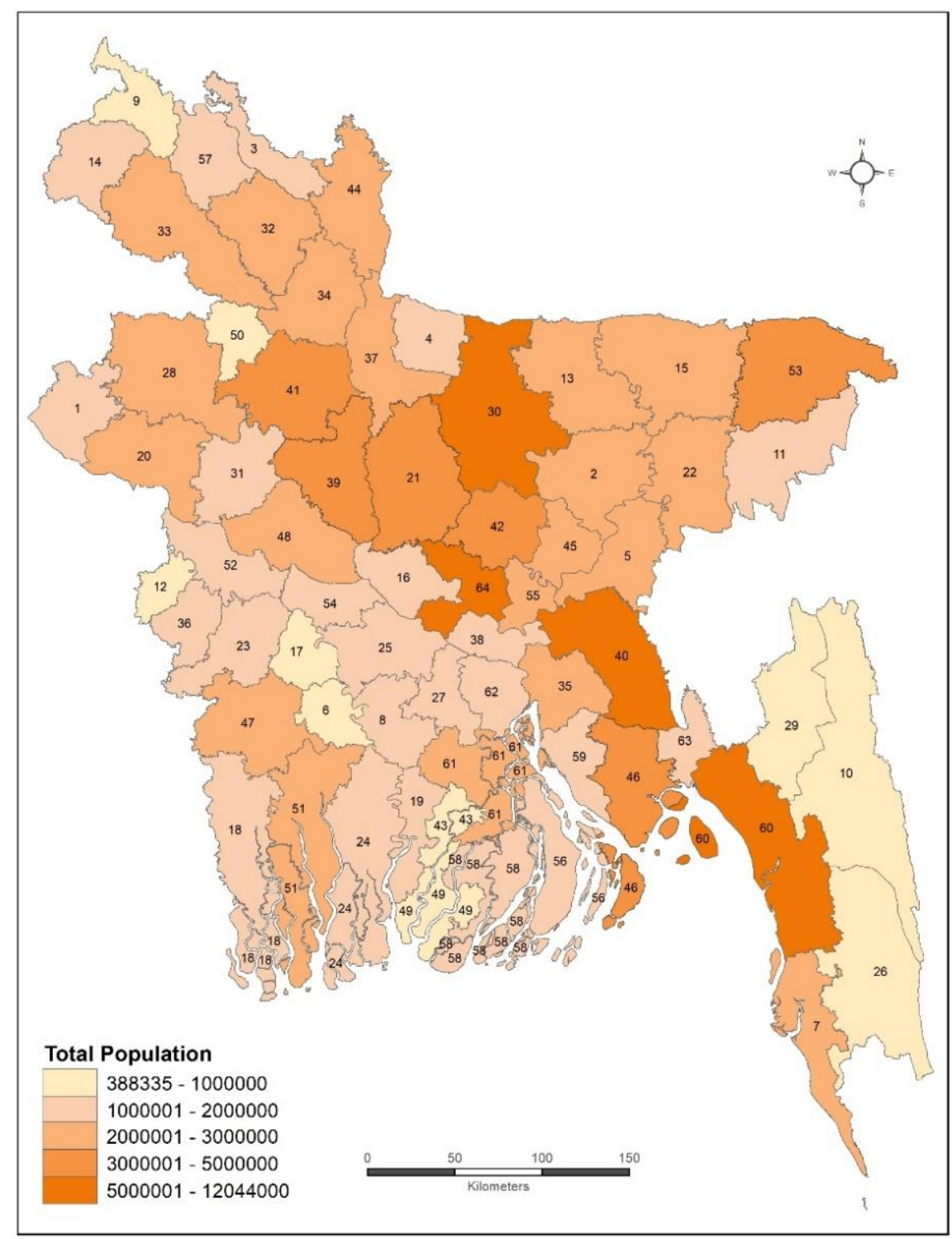

Figure 6 - Map showing the relationship between the total population each district and the lightning death rates per million populations per district. The population has been showing as color shaded and death rates has been showing as rank from 1 to 64 having highest to lowest death rates. 
On the other hand, Chapai-Nawabganj is in the top of the lightning death rates but in terms of population, it is in the lower middle of the list of total population per district. The coastal areas of Bangladesh have small number of population as well the death rates are also lower compared to other areas.

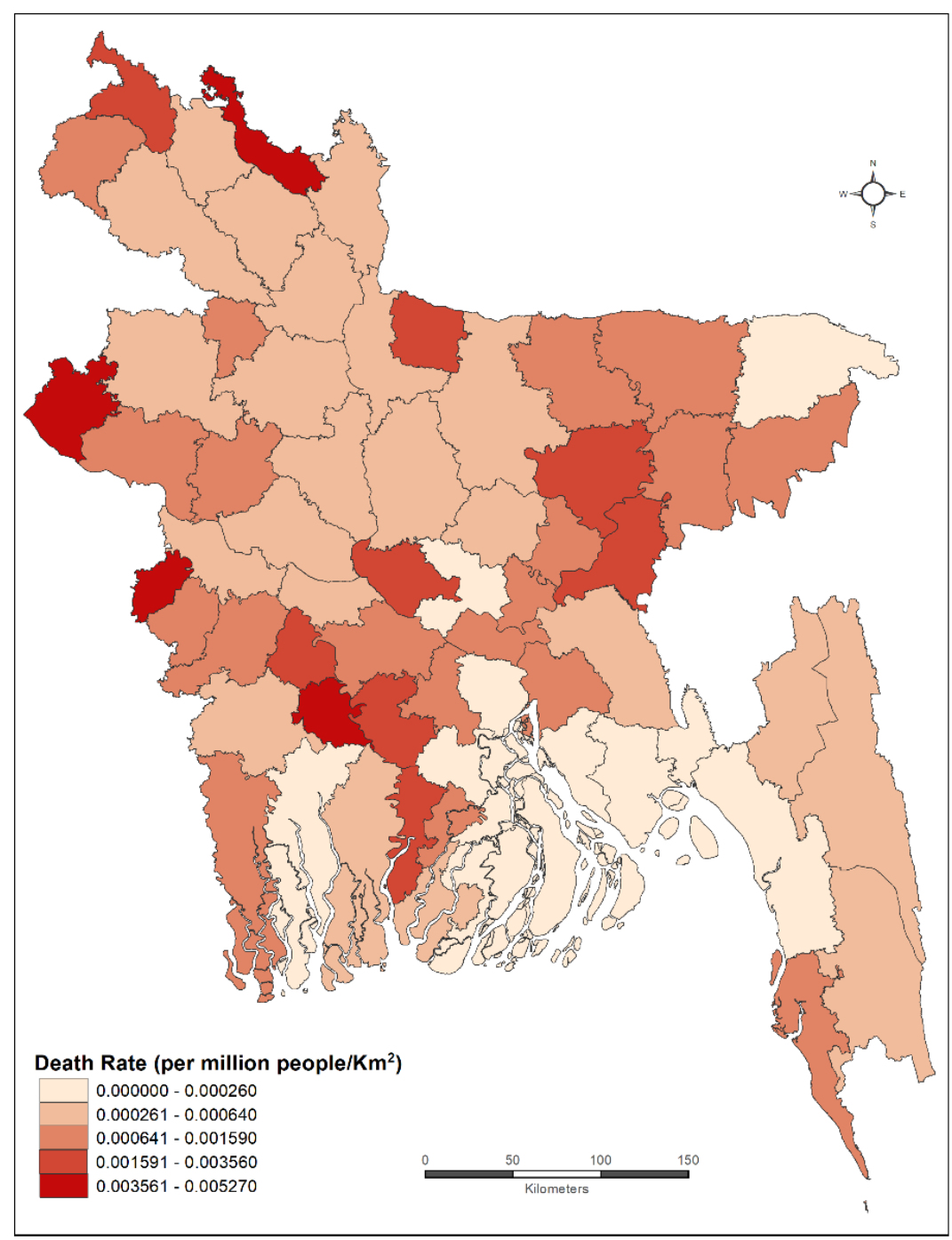

Figure7 - Lightning death rate per million people per year per square kilometer per district.

Fig 7 shows lightning death rate per million people per year per square kilometer per district, the highest rate of deaths found to be in Meherpur (0.00527) and the lowest death rate (0.00006) was 
found in the most northeastern district of Bangladesh named Sylhet district. The hilly and the coastal areas of Bangladesh are having the lower death rates per square kilometer. It is because the number of people living in these districts are very low compared to the total land area of those districts.

\section{Results of Survey Data}

The total number of survey included 287 participants. A summary of the demographics of survey respondents can be found in Table 1. According to 2011 census, the total population is $3,403,912$ (52.2\% male and $47.8 \%$ female) and among total population $62.6 \%$ are literate in Gazipur district. The total population of Kishorganj is 2,911,907 (50.8\% male and $49.2 \%$ female). Among total population, $40.9 \%$ people are literate. In Sunamganj district, total population is $2,467,968$ including $50.1 \%$ male and $49.9 \%$ female population and the percentage of literate people is 35 .

Table 1: Demographic summary of the survey participants

\begin{tabular}{|c|c|c|c|}
\hline Demography & Male & Female & Total \\
\hline Total & $51 \%$ & $49 \%$ & $100 \%$ \\
\hline \multicolumn{4}{|l|}{ Age } \\
\hline 1) $19-40$ Years & $35 \%$ & $46 \%$ & $41 \%$ \\
\hline 2) $41-60$ Years & $38 \%$ & $36 \%$ & $37 \%$ \\
\hline 3) $61-80$ Years & $20 \%$ & $14 \%$ & $17 \%$ \\
\hline 4) $80+$ Years & $7 \%$ & $4 \%$ & $5 \%$ \\
\hline \multicolumn{4}{|l|}{ Education } \\
\hline 1) No Education & $16 \%$ & $11 \%$ & $14 \%$ \\
\hline 2) Primary & $16 \%$ & $18 \%$ & $17 \%$ \\
\hline 3) Secondary & $29 \%$ & $21 \%$ & $25 \%$ \\
\hline 4) Higher Secondary & $21 \%$ & $20 \%$ & $20 \%$ \\
\hline 5) Bachelor & $15 \%$ & $28 \%$ & $21 \%$ \\
\hline 6) Masters & $3 \%$ & $2 \%$ & $3 \%$ \\
\hline
\end{tabular}




\section{Agriculture and Lightning}

Bangladesh is one of the agricultural based country in the world. Most of the people in Bangladesh is directly involved in agriculture for their livelihood. According to World Bank, more than 70 percent of Bangladesh's population live in rural areas and about 87 percent of rural households depend on agriculture for at least part of their income. It is documented that a major portion of people die in Bangladesh are farmers. Of 38 people killed by lightning in Bangladesh on May 12-13, 2016, 61\% were outdoors in agricultural work (Holle and Islam, 2017). Twenty percent of the respondents in this study were farmers. Among the respondents, there are 51 male and 6 female who described their occupation as either farmer or day laborer.

Overall lightning perceptions in Bangladesh

All survey responses were reviewed for percent of responses for each options. The bold options at the table are correct answers. A summary of the responses can be found in Table 2 .

Table 2: Overall lightning safety knowledge and perception percentage

\begin{tabular}{|l|c|}
\hline \multicolumn{1}{|c|}{ Survey Questions } & Response Rate \\
\hline Which season does lightning occur in your locality? & \\
1) Pre-monsoon & $30 \%$ \\
2) Monsoon & $53 \%$ \\
3) Post-monsoon & $8 \%$ \\
4) Whole year & $9 \%$ \\
\hline Has frequency of lightning changed in recent years? & $84 \%$ \\
1) Increased & $10 \%$ \\
2) Decreased & $6 \%$ \\
3) Unchanged & \\
\hline
\end{tabular}


Table 2 (continued)

\begin{tabular}{|c|c|}
\hline $\begin{array}{l}\text { Has lightning death rates changed in recent years? } \\
\text { 1) Increased } \\
\text { 2) Decreased } \\
\text { 3) Unchanged }\end{array}$ & $\begin{array}{c}85 \% \\
11 \% \\
4 \%\end{array}$ \\
\hline $\begin{array}{l}\text { Are you in danger of being struck by lightning while outdoors? } \\
\text { 1) Yes } \\
\text { 2) No }\end{array}$ & $\begin{array}{l}77 \% \\
23 \%\end{array}$ \\
\hline $\begin{array}{l}\text { Did you loss anything due to lightning strikes? } \\
\text { 1) Yes } \\
\text { 2) No }\end{array}$ & $\begin{array}{l}26 \% \\
74 \%\end{array}$ \\
\hline $\begin{array}{l}\text { Was someone you know injured due to lightning strikes? } \\
\text { 1) I have but no one I know has } \\
\text { 2) I have and someone I know has } \\
\text { 3) I have not but someone I know has } \\
\text { 4) Neither I have nor someone I know has }\end{array}$ & $\begin{array}{l}13 \% \\
20 \% \\
43 \% \\
24 \%\end{array}$ \\
\hline $\begin{array}{l}\text { Is there any siren, sign or announcement take place during } \\
\text { lightning in your locality? } \\
\text { 1) Yes } \\
\text { 2) No }\end{array}$ & $\begin{array}{l}25 \% \\
75 \%\end{array}$ \\
\hline $\begin{array}{l}\text { Is there any sign, siren or announcement at your workplace } \\
\text { while working outside of home? } \\
\text { 1) Yes } \\
\text { 2) No }\end{array}$ & $\begin{array}{l}24 \% \\
76 \%\end{array}$ \\
\hline $\begin{array}{l}\text { How do you know lightning is nearby? } \\
\text { 1) Internet or media } \\
\text { 2) Other people } \\
\text { 3) Environmental Changes } \\
\text { 4) None of above }\end{array}$ & $\begin{array}{l}17 \% \\
25 \% \\
47 \% \\
11 \%\end{array}$ \\
\hline $\begin{array}{l}\text { Do you follow weather forecasting on TV/ radio? } \\
\text { 1) Daily } \\
\text { 2) Once or twice in a week } \\
\text { 3) Less than once in a week } \\
\text { 4) No, not at all }\end{array}$ & $\begin{array}{l}16 \% \\
30 \% \\
27 \% \\
27 \%\end{array}$ \\
\hline $\begin{array}{l}\text { Did you get any lightning safety precaution/ training from your } \\
\text { local authority? } \\
\text { 1) Yes } \\
\text { 2) No }\end{array}$ & $\begin{array}{c}4 \% \\
96 \%\end{array}$ \\
\hline
\end{tabular}


Table 2 (continued)

\begin{tabular}{|l|c|}
\hline Do you feel lightning as dangerous? & $34 \%$ \\
1) Sometimes & $15 \%$ \\
2) Rarely & $50 \%$ \\
3) Yes, it's dangerous & $1 \%$ \\
4) No, it is not dangerous & \\
\hline Do you take any shelter if you hear sound of thunder suddenly? & $72 \%$ \\
1) Yes & $16 \%$ \\
2) No & $12 \%$ \\
3) I do not care & \\
\hline Are you already in danger while outdoors hearing thunder? & $80 \%$ \\
1) Yes & $14 \%$ \\
2) No & $6 \%$ \\
3) I don't know & $78 \%$ \\
\hline What are the safe places during thunderstorm? & $12 \%$ \\
1) Inside house & $2 \%$ \\
2) Under tree & $5 \%$ \\
3) Inside car & $3 \%$ \\
4) Open area & \\
5) Others & \\
\hline How long do you usually wait at a safe place after the last & \\
apparent lightning flash? & \\
1) <5 minutes & \\
2) 6-15 minutes & $12 \%$ \\
3) 16-30 minutes & $10 \%$ \\
4) 30+ minutes & $40 \%$ \\
\hline Do you think that strike victims do not carry an electrical \\
charge and may be safely touched? & \\
1) Yes & \\
2) No & \\
\hline Do you look at weather forecast before planning to be \\
outdoors? & \\
1) Always & \\
2) Sometimes & \\
3) Never & \\
\hline
\end{tabular}


Table 2 (Continued)

\begin{tabular}{|c|c|}
\hline $\begin{array}{l}\text { How many people are being killed each year due to lightning in } \\
\text { Bangladesh? }\end{array}$ & \\
\hline 1) $<100$ People & $13 \%$ \\
\hline 2) 101-500 People & $48 \%$ \\
\hline 3) 501-1000 People & $27 \%$ \\
\hline 4) $1000+$ People & $12 \%$ \\
\hline How do you know about the lightning deaths? & \\
\hline 1) Newspaper & $20 \%$ \\
\hline 2) $\mathrm{TV}$ & $30 \%$ \\
\hline 3) Radio & $9 \%$ \\
\hline 4) Internet & $15 \%$ \\
\hline 5) Other People & $26 \%$ \\
\hline Open Ended Questions & Response Rate \\
\hline What activities should not be done during lightning? & \\
\hline 1) Should not use electronic devices & $9 \%$ \\
\hline 2) Should not be outside home & $71 \%$ \\
\hline 3) Should not be outside and use electronic devices & $18 \%$ \\
\hline 4) I don’t know & $2 \%$ \\
\hline What are the reasons behind struck by lightning? & \\
\hline 1) People are careless and go outside & $26 \%$ \\
\hline 2) Lack of shelter & $7 \%$ \\
\hline 3) Lack of safety knowledge and awareness & $16 \%$ \\
\hline 4) Lack of both shelter and awareness & $2 \%$ \\
\hline 5) Lightning has electric charge and attracts human & $34 \%$ \\
\hline 6) Luck & $5 \%$ \\
\hline 7) I don’t know & $10 \%$ \\
\hline $\begin{array}{l}\text { What kind of safety measures do you take when lightning } \\
\text { occurs? }\end{array}$ & \\
\hline 1) Take shelter at a safe place as soon as possible & $79 \%$ \\
\hline $\begin{array}{l}\text { 2) Stay inside home and make sure electronic devices are } \\
\text { off }\end{array}$ & $13 \%$ \\
\hline 3) Nothing to do with lightning & $3 \%$ \\
\hline 4) I don't care & $5 \%$ \\
\hline $\begin{array}{l}\text { What may happen to a person struck by lightning? } \\
\text { 1) Death or injury of body parts }\end{array}$ & $100 \%$ \\
\hline
\end{tabular}


There were some variables that are misunderstood by the people of Bangladesh, which can be considered as inadequate knowledge of lightning. The questions that were misunderstood include How long do you usually wait at a safe place after the last apparent lightning flash and Do you think that strike victims do not carry an electrical charge and may be safely touched? In case of the responses for how long they usually wait at a safe place after the last apparent lightning flash or thunderstorm, most of the respondents (42\%) responded that they wait less than five minutes after the last apparent flash or thunderstorm. The responses suggest that there was misunderstanding of the recommendation to wait at least 30 minutes before going outside from a safe place after the last apparent lightning flash.

Another safety knowledge questions asked about do you think that strike victims do not carry an electrical charge and may be safely touched. The responses showed that $60 \%$ people have responded positively that the lightning strike victims do not carry electrical charge and can be safely touched and $40 \%$ people responded negatively indicates that they believe in this misconception that the lightning strike victims carry electrical charge and cannot be safely touched. A lightning strike victim does not carry any electric charge and can be touched without any caution. It clearly shows that $40 \%$ of the people believe in this misconception.

The responses for safe place during lightning were mostly answered as inside house though there were some responses those are incorrect as safe places. Unwarily or carelessly, the people are taking risk of their lives during the lightning flash in Bangladesh. The question regarding What are the reasons behind struck by lightning responses were found that a major portion of people (26\%) go outside and are careless about the risk of being struck by lightning in Bangladesh. Some respondents think that it is a matter of luck and they have nothing to do with lightning. About $10 \%$ people responded that they do not know why people are being struck by 
lightning in Bangladesh. It clearly indicates that they need to be informed of the safety rules, awareness should be increased among them and proper and right information should be disseminating among the mass people in Bangladesh. People should be more conscious about the safety rules about lightning or the death tolls will rise constantly in Bangladesh due to lightning.

\section{Gender and Lightning Safety Knowledge and Perceptions}

Survey responses were compared to determine whether gender was related to overall lightning safety knowledge and perceptions. The survey responses of both genders as well as a test for significance was used to determine the relationships of gender on overall responses. A summary of the responses for each gender can be found in Table 3.

Table 3: Male and female percentage of responses and P-values for a test of difference between genders.

\begin{tabular}{|l|c|c|c|c|}
\hline \multirow{2}{*}{ Survey Questions } & \multicolumn{2}{|c|}{ Responses } & \multirow{2}{*}{$\begin{array}{c}\text { Expected } \\
\text { Count <5 }\end{array}$} & \multirow{2}{*}{ P- Value } \\
\cline { 2 - 3 } & Male & Female & & \\
\hline Which season does lightning occur in & & & & \\
your locality? & $25 \%$ & $35 \%$ & \multirow{2}{*}{ No } & \multirow{2}{*}{0.37434} \\
1) Pre-monsoon & $56 \%$ & $50 \%$ & & \\
2) Monsoon & $9 \%$ & $7 \%$ & & \\
3) Post-monsoon & $10 \%$ & $8 \%$ & & \\
4) Whole year & & & & \\
\hline Has frequency of lightning changed in & & & \\
recent years? & $84 \%$ & $84 \%$ & & \\
1) Increased & $10 \%$ & $11 \%$ & No & \\
2) Decreased & $6 \%$ & $5 \%$ & & \\
3) Unchanged & & & & \\
\hline
\end{tabular}


Table 3 (Continued)

\begin{tabular}{|c|c|c|c|c|}
\hline $\begin{array}{l}\text { Has lightning death rates changed in } \\
\text { recent years? } \\
\text { 1) Increased } \\
\text { 2) Decreased } \\
\text { 3) Unchanged }\end{array}$ & $\begin{array}{c}84 \% \\
13 \% \\
3 \%\end{array}$ & $\begin{array}{c}86 \% \\
9 \% \\
5 \%\end{array}$ & No & 0.33443 \\
\hline $\begin{array}{l}\text { Are you in danger of being struck by } \\
\text { lightning while outdoors? } \\
\text { 1) Yes } \\
\text { 2) No }\end{array}$ & $\begin{array}{l}71 \% \\
29 \%\end{array}$ & $\begin{array}{l}83 \% \\
17 \%\end{array}$ & No & $\underline{0.01282}$ \\
\hline $\begin{array}{l}\text { Did you loss anything due to lightning } \\
\text { strikes? } \\
\text { 1) Yes } \\
\text { 2) No }\end{array}$ & $\begin{array}{l}31 \% \\
69 \%\end{array}$ & $\begin{array}{l}21 \% \\
79 \%\end{array}$ & No & $\underline{0.04710}$ \\
\hline $\begin{array}{l}\text { Was someone you know injured due to } \\
\text { lightning strikes? } \\
\text { 1) I have but no one I know has } \\
\text { 2) I have and someone I know has } \\
\text { 3) I have not but someone I know has } \\
\text { 4) Neither I have nor I know has }\end{array}$ & $\begin{array}{l}19 \% \\
27 \% \\
36 \% \\
18 \%\end{array}$ & $\begin{array}{l}7 \% \\
13 \% \\
50 \% \\
30 \%\end{array}$ & No & $\underline{0.00005}$ \\
\hline $\begin{array}{l}\text { Is there any siren, sign or announcement } \\
\text { take place during lightning in your } \\
\text { locality? } \\
\text { 1) Yes } \\
\text { 2) No }\end{array}$ & $\begin{array}{l}32 \% \\
68 \%\end{array}$ & $\begin{array}{l}18 \% \\
82 \%\end{array}$ & No & $\underline{0.00473}$ \\
\hline $\begin{array}{l}\text { Is there any sign, siren or announcement } \\
\text { at your workplace while working outside } \\
\text { of home? } \\
\text { 1) Yes } \\
\text { 2) No }\end{array}$ & $\begin{array}{l}27 \% \\
73 \%\end{array}$ & $\begin{array}{l}21 \% \\
79 \%\end{array}$ & No & 0.22739 \\
\hline $\begin{array}{l}\text { How do you know lightning is nearby? } \\
\text { 1) Internet or media } \\
\text { 2) Other people } \\
\text { 3) Environmental Changes } \\
\text { 4) None of above }\end{array}$ & $\begin{array}{l}17 \% \\
25 \% \\
48 \% \\
10 \%\end{array}$ & $\begin{array}{l}17 \% \\
25 \% \\
45 \% \\
13 \%\end{array}$ & No & 0.85954 \\
\hline
\end{tabular}


Table 3 (Continued)

\begin{tabular}{|c|c|c|c|c|}
\hline $\begin{array}{l}\text { Do you follow weather forecasting on TV/ } \\
\text { radio? } \\
\text { 1) Daily } \\
\text { 2) Once or twice in a week } \\
\text { 3) Less than once in a week } \\
\text { 4) No, not at all }\end{array}$ & $\begin{array}{l}14 \% \\
35 \% \\
30 \% \\
21 \%\end{array}$ & $\begin{array}{l}18 \% \\
25 \% \\
24 \% \\
33 \%\end{array}$ & No & $\underline{0.04065}$ \\
\hline $\begin{array}{l}\text { Did you get any lightning safety } \\
\text { precaution/ training from your local } \\
\text { authority? } \\
\text { 1) Yes } \\
\text { 2) No }\end{array}$ & $\begin{array}{c}3 \% \\
97 \%\end{array}$ & $\begin{array}{c}5 \% \\
95 \%\end{array}$ & No & 0.51468 \\
\hline $\begin{array}{l}\text { Do you feel lightning as dangerous? } \\
\text { 1) Sometimes but not always } \\
\text { 2) Rarely they are dangerous } \\
\text { 3) Yes, it's dangerous } \\
\text { 4) No, it is not dangerous }\end{array}$ & $\begin{array}{c}38 \% \\
16 \% \\
44 \% \\
2 \%\end{array}$ & $\begin{array}{c}30 \% \\
14 \% \\
55 \% \\
1 \%\end{array}$ & Yes(2) & 0.37731 \\
\hline $\begin{array}{l}\text { Do you take any shelter if you hear sound } \\
\text { of thunder suddenly? } \\
\text { 1) Yes } \\
\text { 2) No } \\
\text { 3) I do not care }\end{array}$ & $\begin{array}{l}65 \% \\
22 \% \\
13 \%\end{array}$ & $\begin{array}{l}79 \% \\
11 \% \\
10 \%\end{array}$ & No & $\underline{0.02047}$ \\
\hline $\begin{array}{l}\text { Are you already in danger while outdoors } \\
\text { hearing thunder? } \\
\text { 1) Yes } \\
\text { 2) No } \\
\text { 3) I don't know }\end{array}$ & $\begin{array}{c}77 \% \\
19 \% \\
4 \%\end{array}$ & $\begin{array}{c}82 \% \\
9 \% \\
9 \%\end{array}$ & No & $\underline{0.03248}$ \\
\hline $\begin{array}{l}\text { What are the safe places during } \\
\text { thunderstorm? } \\
\text { 1) Inside house } \\
\text { 2) Under tree } \\
\text { 3) Inside car } \\
\text { 4) Open area } \\
\text { 5) Others }\end{array}$ & $\begin{array}{l}72 \% \\
14 \% \\
5 \% \\
6 \% \\
3 \%\end{array}$ & $\begin{array}{l}83 \% \\
11 \% \\
1 \% \\
4 \% \\
1 \%\end{array}$ & Yes(4) & 0.13917 \\
\hline
\end{tabular}


Table 3 (Continued)

\begin{tabular}{|c|c|c|c|c|}
\hline $\begin{array}{l}\text { How long do you usually wait at a safe } \\
\text { place after the last apparent lightning } \\
\text { flash? } \\
\text { 1) }<5 \text { minutes } \\
\text { 2) } 6-15 \text { minutes } \\
\text { 3) } 16-30 \text { minutes } \\
\text { 4) } \mathbf{3 0 +} \text { minutes }\end{array}$ & $\begin{array}{c}42 \% \\
45 \% \\
6 \% \\
7 \%\end{array}$ & $\begin{array}{l}42 \% \\
27 \% \\
18 \% \\
13 \%\end{array}$ & No & $\underline{0.00048}$ \\
\hline $\begin{array}{l}\text { Do you think that strike victims do not } \\
\text { carry an electrical charge and may be } \\
\text { safely touched? } \\
\text { 1) Yes } \\
\text { 2) No }\end{array}$ & $\begin{array}{l}62 \% \\
38 \%\end{array}$ & $\begin{array}{l}57 \% \\
43 \%\end{array}$ & No & 0.334572 \\
\hline $\begin{array}{l}\text { Do you look at weather forecast before } \\
\text { planning to be outdoors? } \\
\text { 1) Always } \\
\text { 2) Sometimes } \\
\text { 3) Never }\end{array}$ & $\begin{array}{l}14 \% \\
45 \% \\
41 \%\end{array}$ & $\begin{array}{l}16 \% \\
42 \% \\
42 \%\end{array}$ & No & 0.76999 \\
\hline $\begin{array}{l}\text { How many people are being killed each } \\
\text { year due to lightning in Bangladesh? } \\
\text { 1) }<100 \text { People } \\
\text { 2) } 101-500 \text { People } \\
\text { 3) } 501-1000 \text { People } \\
\text { 4) } 1000+\text { People }\end{array}$ & $\begin{array}{l}10 \% \\
50 \% \\
30 \% \\
10 \%\end{array}$ & $\begin{array}{l}16 \% \\
47 \% \\
24 \% \\
13 \%\end{array}$ & No & 0.35442 \\
\hline $\begin{array}{l}\text { How do you know about the lightning } \\
\text { deaths? } \\
\text { 1) Newspaper } \\
\text { 2) TV } \\
\text { 3) Radio } \\
\text { 4) Internet } \\
\text { 5) Other People }\end{array}$ & $\begin{array}{l}26 \% \\
23 \% \\
14 \% \\
14 \% \\
23 \%\end{array}$ & $\begin{array}{c}13 \% \\
38 \% \\
4 \% \\
16 \% \\
29 \%\end{array}$ & No & $\underline{0.00028}$ \\
\hline
\end{tabular}

In comparison between male and female, most of the responses rate were not statistically different. Responses to some questions were significantly different between genders $(\mathrm{p}<0.05)$. These variables included Hearing thunder means being in danger of being struck by lightning, 
Personal loss due to lightning strikes, someone you know are injured due to lightning strikes, Siren, sign or announcement of lightning at locality, regularly look at the weather forecasting on TV/Radio, taking shelter while hearing thunder suddenly, while outdoors, you are in danger during thunder, Waiting minutes at a safe place after the last apparent thunder, and how do you know about the lightning deaths.

Regarding the question if you are outside and hear thunder, do you think you are in danger of being stuck by lightning $71 \%$ of males responded yes compared to $83 \%$ of female respondents. It suggests that females are more careful and cautious about the possible lightning accident. Previous research has found that most people die due to lightning while they work at their agricultural field. Male population is the majority in terms of number of farmers in Bangladesh. In regarding the question do you take any shelter if you hear sound of thunder suddenly, $65 \%$ of males take shelter during lightning comparing with $79 \%$ of females taking shelter when they hear thunder suddenly. In terms of the wait time at a safe place after the last apparent lightning flash or thunder, male populations are quicker to go outside in comparing with the female population. About $87 \%$ male population wait less than 15 minutes in comparing with $69 \%$ female population. From the comparison between male and female, it was found that male populations tend to go outside quicker than the female population. Though it is recommended to go outside after 30 minutes of the last apparent flash, both genders go outside after the last apparent lightning flash or thunderstorm within less than 30 minutes. Both male and female are making their life in danger of being stuck by lightning.

While asking the question, Have you or someone you know ever been injured due to lightning strikes, $13 \%$ people has responded as they were injured and $20 \%$ has responded that they have and they know someone has (Table 2). The result finding seems very high percentage 
of people having injury. There might be some linguistic problems while asking question as the questionnaire was in English but it was conducted in another country having different language. However, the study area from three districts were selected based on the higher population deaths area.

\section{Lightning Safety Knowledge and Education}

To look at the perceptions of university graduates among the all respondents, all variables were used and significance were analyzed. The summary of the responses of the graduates can be found in the following table.

Table 4: Education and lightning safety knowledge and perceptions

\begin{tabular}{|c|c|c|c|c|c|}
\hline \multirow{2}{*}{ Survey Questions } & \multicolumn{4}{|c|}{ Responses } & \multirow{2}{*}{ P- Value } \\
\cline { 2 - 5 } & $\begin{array}{l}\text { No } \\
\text { Education }\end{array}$ & $\begin{array}{c}\text { Primary } \\
\text { Education }\end{array}$ & $\begin{array}{c}\text { Secondary } \\
\text { Education }\end{array}$ & $\begin{array}{c}\text { University } \\
\text { Education }\end{array}$ & \\
\hline Which season does lightning & & & & & \\
occur in your locality? & & & & \\
1) Pre-monsoon & $10 \%$ & $54 \%$ & $29 \%$ & $25 \%$ & \\
2) Monsoon & $64 \%$ & $23 \%$ & $50 \%$ & $74 \%$ & - \\
3) Post-monsoon & $18 \%$ & $3 \%$ & $10 \%$ & $0 \%$ & \\
4) Whole year & $8 \%$ & $20 \%$ & $11 \%$ & $1 \%$ & \\
\hline Has frequency of lightning & & & & & \\
changed in recent years? & & & & & \\
1) Increased & $85 \%$ & $86 \%$ & $82 \%$ & $86 \%$ & \\
2) Decreased & $13 \%$ & $6 \%$ & $11 \%$ & $9 \%$ & \\
3) Unchanged & $2 \%$ & $8 \%$ & $7 \%$ & $5 \%$ & \\
\hline Has lightning death rates & & & & & \\
changed in recent years? & & & & & \\
1) Increased & $82 \%$ & $90 \%$ & $86 \%$ & $80 \%$ & \multirow{2}{*}{0.11763} \\
2) Decreased & $15 \%$ & $4 \%$ & $8 \%$ & $18 \%$ & \\
3) Unchanged & $3 \%$ & $6 \%$ & $6 \%$ & $2 \%$ & \\
\hline
\end{tabular}


Table 4 (Continued)

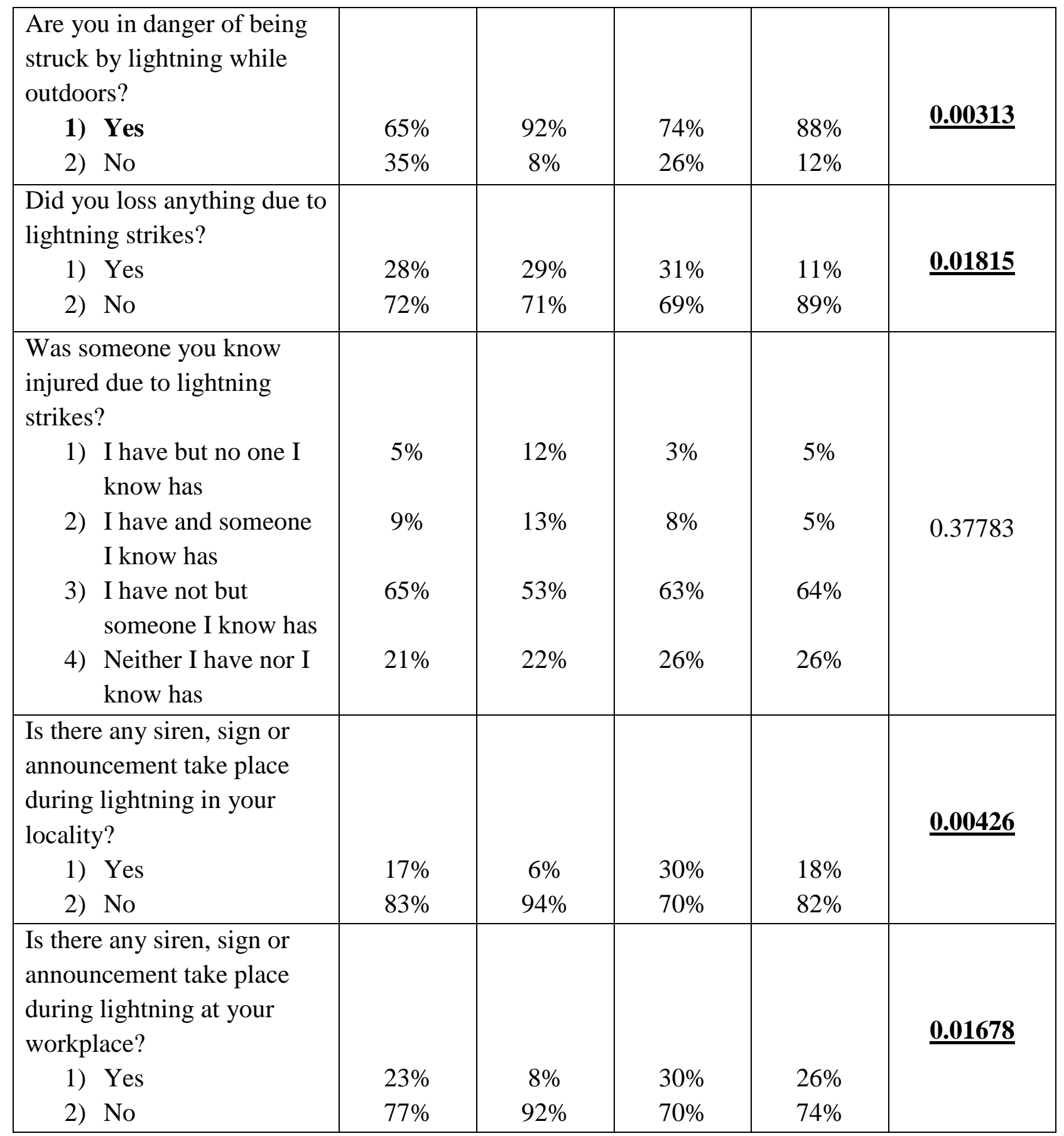


Table 4 (Continued)

\begin{tabular}{|c|c|c|c|c|c|}
\hline $\begin{array}{l}\text { How do you know lightning } \\
\text { is nearby? }\end{array}$ & & & & & \\
\hline 1) Internet or media & $10 \%$ & $6 \%$ & $19 \%$ & $28 \%$ & \\
\hline 2) Other people & $31 \%$ & $33 \%$ & $27 \%$ & $6 \%$ & 000007 \\
\hline $\begin{array}{l}\text { 3) Environmental } \\
\text { Changes }\end{array}$ & $36 \%$ & $59 \%$ & $42 \%$ & $57 \%$ & 0.00001 \\
\hline 4) None of above & $23 \%$ & $2 \%$ & $12 \%$ & $9 \%$ & \\
\hline $\begin{array}{l}\text { Do you follow weather } \\
\text { forecasting on TV/Radio? }\end{array}$ & & & & & \\
\hline 1) Daily & $5 \%$ & $2 \%$ & $17 \%$ & $31 \%$ & \\
\hline $\begin{array}{l}\text { 2) Once or twice in a } \\
\text { week }\end{array}$ & $36 \%$ & $16 \%$ & $37 \%$ & $23 \%$ & 0000000000 \\
\hline $\begin{array}{l}\text { 3) Less than once in a } \\
\text { week }\end{array}$ & $21 \%$ & $20 \%$ & $27 \%$ & $32 \%$ & \\
\hline 4) No, not at all & $28 \%$ & $62 \%$ & $19 \%$ & $14 \%$ & \\
\hline $\begin{array}{l}\text { Did you get any lightning } \\
\text { safety precaution or training } \\
\text { from your local authority? }\end{array}$ & & & & & \\
\hline 1) Yes & $3 \%$ & $2 \%$ & $7 \%$ & $2 \%$ & 0.23022 \\
\hline 2) No & $97 \%$ & $98 \%$ & $93 \%$ & $98 \%$ & \\
\hline $\begin{array}{l}\text { Do you feel lightning as } \\
\text { dangerous? }\end{array}$ & & & & & \\
\hline 1) Sometimes & $31 \%$ & $35 \%$ & $41 \%$ & $23 \%$ & \\
\hline 2) Rarely & $31 \%$ & $18 \%$ & $17 \%$ & $2 \%$ & - \\
\hline 3) Yes, it's dangerous & $38 \%$ & $47 \%$ & $41 \%$ & $75 \%$ & \\
\hline $\begin{array}{l}\text { 4) No, it is not } \\
\text { dangerous }\end{array}$ & $0 \%$ & $0 \%$ & $1 \%$ & $0 \%$ & \\
\hline $\begin{array}{l}\text { Do you take any shelter if } \\
\text { you hear sound of thunder } \\
\text { suddenly? }\end{array}$ & & & & & \\
\hline 1) Yes & $65 \%$ & $78 \%$ & $75 \%$ & $94 \%$ & $\underline{0.01099}$ \\
\hline 2) No & $20 \%$ & $9 \%$ & $13 \%$ & $4 \%$ & \\
\hline 3) I do not care & $15 \%$ & $13 \%$ & $12 \%$ & $2 \%$ & \\
\hline
\end{tabular}


Table 4 (Continued)

\begin{tabular}{|l|c|c|c|c|c|}
\hline $\begin{array}{l}\text { Are you already in danger } \\
\text { while outdoors hearing } \\
\text { thunder? }\end{array}$ & & & & & \\
1) Yes & $64 \%$ & $82 \%$ & $79 \%$ & $89 \%$ & $\underline{\mathbf{0 . 0 0 0 8 5}}$ \\
2) No & $33 \%$ & $10 \%$ & $16 \%$ & $2 \%$ & \\
3) I don't know & $3 \%$ & $8 \%$ & $5 \%$ & $9 \%$ & \\
\hline $\begin{array}{l}\text { What are the safe places } \\
\text { during thunderstorm? }\end{array}$ & & & & & \\
1) Inside house & $59 \%$ & $90 \%$ & $74 \%$ & $89 \%$ & \\
2) Under tree & $0 \%$ & $4 \%$ & $14 \%$ & $4 \%$ & \\
3) Inside car & $8 \%$ & $6 \%$ & $5 \%$ & $2 \%$ & \\
4) Open area & $5 \%$ & $0 \%$ & $2 \%$ & $2 \%$ & \\
5) Others & & & & & \\
\hline How long do you usually & & & & & \\
wait at a safe place after the & & & & & \\
last apparent lightning & & & & & \\
flash? & & & & & \\
1) <5 minutes & $31 \%$ & $43 \%$ & $37 \%$ & $58 \%$ & $\mathbf{0 . 0 3 0 5 2}$ \\
2) 6-15 minutes & $56 \%$ & $29 \%$ & $40 \%$ & $22 \%$ & \\
3) 16-30 minutes & $10 \%$ & $12 \%$ & $12 \%$ & $12 \%$ & \\
4) 30+ minutes & $3 \%$ & $16 \%$ & $11 \%$ & $8 \%$ & \\
\hline $\begin{array}{l}\text { Do you think that strike } \\
\text { victims do not carry an }\end{array}$ & & & & & \\
electrical charge and may be \\
safely touched?
\end{tabular}


Table 4 (Continued)

\begin{tabular}{|l|c|c|c|c|c|}
\hline $\begin{array}{l}\text { How many people are being } \\
\text { killed each year due to } \\
\text { lightning in Bangladesh? }\end{array}$ & & & & & \\
1) <100 People & $3 \%$ & $4 \%$ & $9 \%$ & $34 \%$ & \\
2) 101-500 People & $49 \%$ & $47 \%$ & $48 \%$ & $49 \%$ & $\underline{\mathbf{0 . 0 1 1 8 3}}$ \\
3) 501-1000 People & $41 \%$ & $27 \%$ & $31 \%$ & $11 \%$ & \\
4) 1000+ People & $7 \%$ & $22 \%$ & $12 \%$ & $6 \%$ & \\
\hline How do you know about the & & & & & \\
lightning deaths? & $2 \%$ & $10 \%$ & $23 \%$ & $26 \%$ & \\
1) Newspaper & $40 \%$ & $20 \%$ & $23 \%$ & $51 \%$ & - \\
2) TV & $19 \%$ & $8 \%$ & $12 \%$ & $2 \%$ & \\
3) Radio & $0 \%$ & $2 \%$ & $23 \%$ & $18 \%$ & \\
4) Internet & $39 \%$ & $60 \%$ & $19 \%$ & $3 \%$ & \\
5) Other People & & & \\
\hline
\end{tabular}

To determine if education levels of the survey respondents are related to overall responses, a chisquare test were conducted. A significant difference $(\mathrm{p}<0.05)$ was found for 12 survey questions. These included If you are outside and hear thunder, do you think you are in danger of being stuck by lightning, have you ever lost anything due to lightning strikes, is there any siren, sign or announcement take place during lightning in your locality, if you are working outside of your home, do you hear any sign, siren or announcement at your workplace while working, how do you know lightning is nearby, do you regularly look at the weather forecasting on TV/ radio, Do you take any shelter if you hear sound of thunder suddenly, If you hear thunder while you're outdoors, do you think that you're already in danger, How long do you usually wait at a safe place after the last apparent lightning flash or thunder, Do you think that strike victims do not carry an electrical charge and may be safely touched, Do you look at a weather forecast before planning to be outdoors and How many people do you think are being killed each year due to lightning in Bangladesh. 
Some of the most widely misunderstood lightning safety knowledge variables included waiting minutes at a safe place after the last apparent thunder before resuming outdoor activities; Strike victims do not carry electrical charge and may be safely touched, while outdoors, you are in danger during thunder and Safe place during thunderstorm. The question regarding number of minutes to wait after the last apparent lightning flash before resuming outdoor activities was widely misunderstood among the respondents.

Most of the respondents in this category responded that they wait less than the number of minutes they should wait before resuming outdoor activities after the last apparent lightning flash or thunderstorm. To be safe from lightning, everyone should wait 30 minutes after hearing the last apparent lightning flash before resuming outdoor activities. However, the responses suggested that even the educated people underestimates this rule to wait 30 minutes before resuming outdoor activities. Most of the respondent answered less than 15 minutes. Even educated people in Bangladesh are putting themselves in danger by underestimating the standard that should be followed to be safe from lightning.

The question regarding if strike victims do not carry an electrical charge and may be safely touched was another most widely misunderstood among the people in Bangladesh. The low p-value (0.00132) is indicating that the perception differs among different education group. Though the lightning victims do not carry an electrical charge and can be safely touched, approximately $60 \%$ of the respondents having university degree think that the lightning strike victims cannot be safely touched and they carry electric charge that is widely misunderstood in Bangladesh. The responses suggest that even the educated people have poor information about the lightning safety knowledge and awareness. About $40 \%$ of the respondents having university degree believe that the lightning victims do not carry electrical charge and can be safely touched. 
The question regarding Safe place during thunderstorm was mostly answered inside house though there are some answers that were misunderstood. It is proved that the safest place during lightning flash is to be inside house. While asking the question which place is safe when a thunderstorm is in the area, majority of the respondents that inside house is safe place during thunderstorm as expected. However, some people has responded that under tree or even open area is the safe place during thunderstorm lightning flash that are misunderstood. Some questions were asked about the key information about lightning in Bangladesh. The questions include if the number of lightning increases, if the lightning deaths increased over the last few years and how many people each year are being killed in Bangladesh due to lightning. A major portion of the responses was misinformed among the people in Bangladesh. This study has found that higher education does not mean that the people are more informed and cautious about lightning in Bangladesh. 


\section{CHAPTER 5}

\section{Discussion}

\section{Discussion}

This study includes three types of data to find the relationship between each other. The data sources include lightning deaths data, lightning strikes data and the questionnaire survey data. It was found that the rates of lightning deaths are higher having higher rates of lightning strikes simultaneously. The survey was conducted in three out of sixty-four districts in Bangladesh. The districts include Kishorganj, Sunamganj and Gazipur districts having high, moderate and low death rates. After these three types of data analysis, it was found to have strong relations with each other. People's perceptions depict why the large number of people are being killed in the lightning strikes prone areas in Bangladesh.

It was found that the highest rate per million people per district was 6.68 and the lowest rate of deaths per million people per district was 0.19 . The rate per million people per district was found to be higher in the districts of Kishorganj, Chapai-Nawabganj, Netrokona, Thakurgoan. The lowest rates of death found to be in the districts close to the coastal area and in the central part of Dhaka. The rate in Dhaka district is found to be one of the lowest rates of death having around 15 million people living in this district and only a few people die each year in this capital city of Bangladesh. The factors behind these low death rates might be that the people are more educated, better infrastructure and mostly urban and industrialized area. 
This study has analyzed the LIS datasets from 1998 to 2013 of TRMM mission of NASA to look at the spatial variation of lightning strikes. It was found that the northern and northeastern part of Bangladesh is experiencing the highest rates of lightning flash annually. On the other hand, the coastal areas and the lower southwestern part of Bangladesh is experiencing lower rates of lightning strikes. While working on the seasonal variation of lightning strikes, it was found that during pre-monsoon season Bangladesh experience the highest rates of lightning flash $(0.4927 \mathrm{fl}$ $\mathrm{km}^{-2}$ day $^{-1}$ ). The lowest rate of flash density is found to be during winter season in Bangladesh. The highest rate of lightning flash move from one geographical locations to another if the season changes makes the move like finishing the full circle.

Among the variables in survey questions, do you feel lightning is dangerous, if you hear thunder while you're outdoors, do you think that you're already in danger, which place is safe when a thunderstorm is in the area, how long do you usually wait at a safe place after the last apparent lightning flash or thunder, do you think that strike victims do not carry an electrical charge and may be safely touched are most widely misunderstood variables in this research study. Minutes to wait at a safe place after the last apparent lightning flash or thunder had very low rate of correct responses. The correct response is 30 minutes but most of the responses were recorded lower than 30 minutes. About $42 \%$ respondents has responded that they wait less than 5 minutes after the last lightning flash and $36 \%$ people has responded that they wait 6 to 15 minutes before resuming the outdoor activities after the last apparent lightning flash.

Another misunderstood variable of this study is if strike victims do not carry an electrical charge and may be safely touched. Approximately $60 \%$ of the respondents has responded 
positively and $40 \%$ of the respondents has answered negatively. Though the lightning victims do not carry an electrical charge and can be safely touched, approximately $40 \%$ of the respondents think that the lightning strike victims cannot be safely touched and they carry electric charge. People should be informed about the proper safety rules regarding the lightning accident.

Gender did affect the rate of responses for some variables about the lightning safety knowledge and perceptions. Females were found to be more conscious and careful than male to be safe from lightning accidents. The variables those were differed among male and females include hearing thunder means being in danger of being struck by lightning, lightning is dangerous, taking shelter while hearing thunder suddenly, and while outdoors, you are in danger during lightning. The response regarding hearing thunder means being in danger of being struck by lightning $71 \%$ male responded positively compared to the $83 \%$ female responses that is a bit higher. In response to the question, Taking shelter while hearing thunder suddenly $65 \%$ male has responded yes compared to the $79 \%$ female responses. However, the difference of response rate among male and female was minimal and cannot be concluded that females are more careful and aware about all variables regarding the safety rules to be safe from lightning.

Education level of the respondents had an overall effect on most of the variables of this study. Most of the variables had P-value lower than 0.05 indicates that the education level had an overall impact on the response rate in this study. The variables regarding safety knowledge had P-value lower than 0.05 included Hearing thunder means being in danger of being struck by lightning, Strike victims do not carry electrical charge and may be safely touched and While outdoors, you are in danger during thunder. It was found that there is mixed response rate on different variables of lightning safety knowledge and perceptions among different educational group of people. However, there is difference in response rate among different educational group 
of respondent, it does not conclude that the higher educated people are more conscious, cautious, careful or informed about lightning in Bangladesh.

\section{Recommendations}

- Establishment of lightning safety shelter throughout the country. As it is documented that the farmers are the most common victims of lightning, shelter should be established near the agricultural field so that farmers can take shelter when they are working in the field.

- Government needs to require effective natural hazard education including lightning among much people as there is wide misconceptions and myths among different demographic people.

- Proper weather forecasting and warning system should be installed and disseminate the news among all levels of people as there is no proper sign, siren or announcement at residential as well as commercial area.

- Proper information about the lightning hazard precautions, preventive measures and awareness should be disseminated, as some believe in myths. Some people do not know what are the proper action need to take before, during and after lightning occurrence.

- Role of gender in lightning hazard awareness should be studied more rigorously as it is found that there is perception difference between male and female participants. Further research should be conducted on the role of gender, educational level and how the awareness and experiences of people differ from a lightning prone area to a less lightning prone area in Bangladesh.

- As there is lack of resources, government cannot do everything for the betterment of the people, so people at all levels should come up together to improve the policy and the conditions in Bangladesh. 


\section{CHAPTER 6}

\section{Conclusion}

The results of this study show that there are several areas of lightning safety knowledge and awareness that were misunderstood among the people in Bangladesh. A portion of the people does not know the proper information regarding lightning safety. People believe in misinformation and myths that have been inherited from generation to generation. There is no comprehensive planning to reduce the rate of mortality due to lightning. There is lack of shelters that is one of the key factors of increasing lightning deaths in the rural areas. In terms of gender responses, females are more conscious and careful about lightning accidents compared to males. Education levels also are related to the perceptions of the lightning safety knowledge and awareness, but more education did not always relate to proper knowledge.

This is evident that the numbers of death due to lightning in the world is decreasing but in Bangladesh it is found to be increasing. The main reasons behind this large number of deaths are lack of lightning safety knowledge and awareness, lack of shelters, lack of lightning safety precaution training, lack of proper planning and policy from the government. A lot work to be done to make the situation safer for the people. To improve this situation a comprehensive plan and policy should be developed. Further research should be conducted to make the policy and plan effective for the mass people. Lightning safety information should be disseminating among the peoples of all class and levels. Training should be initiate throughout the country to make people are conscious and aware about lightning. Information about lightning should be included 
in the textbook so that children can learn about lightning from their childhood. All stakeholders from all levels should come up together to minimize the loss of lives. To make the situation better people should stand out from their point. All these steps are vital to increase awareness among people and improving the tools for proper planning and decision making to minimize the loss of lives and property in Bangladesh.

\section{Limitations}

The main and foremost limitation of this study is the number of questionnaires. In this study, 287 surveys were conducted in three districts of Bangladesh. This study only has been conducted in three districts out of sixty-four districts in Bangladesh. To make this research more rigorous, a large number of surveys should be conducted throughout the country. It is near to impossible to conduct a large number of survey with limited time, money and logistic support.

Another limitation of this study was the study area. The study areas were chosen from only one part of the country. The three districts are adjacent to each other. If the three districts were chosen from three different regions of Bangladesh, the research could come up with the differences of lightning safety knowledge and perceptions among the people of different regions. It is believed that the perception of lightning differs from region to region because of the variation of lightning strikes over a large geographical area. Further research should be conducted to validate this statement.

The final limitation of this research was found to be that this research did not look on the policy and practice of lightning safety provided by government or other sources. This research only looked on the people's perception not the facilities, policy or practice available in 
Bangladesh. That might be helpful to come up with the possible solutions regarding improvement of the lightning situation in Bangladesh. A further research on comprehensive study on lightning by engaging all types of stakeholders including the mass people, government official and NGO working on lightning in Bangladesh might be helpful for the better planning to reduce the rate of deaths in Bangladesh. 


\section{Bibliography}

Albrecht, R. I., Goodman, S. J., Buechler, D. E., Blakeslee, R. J., \& Christian, H. J. (2016a). Where are the lightning hotspots on Earth? Bulletin of the American Meteorological Society, 97(11), 2051-2068.

Albrecht, R., S. Goodman, D. Buechler, R. Blakeslee, and H. Christian. (2016b). LIS 0.1 Degree Very High Resolution Gridded Lightning Climatology Data Collection. Data sets available online: http://dx.doi.org/10.5067/LIS/LIS/DATA306

Alcántara-Ayala, I. (2002). Geomorphology, natural hazards, vulnerability and prevention of natural disasters in developing countries. Geomorphology, 47(2), 107-124.

BBS, 2015. Statistical pocketbook of Bangladesh, Bangladesh Bureau of Statistics.

Blaikie, P., Cannon, T., Davis, I., \& Wisner, B. (2014). At risk: natural hazards, people's vulnerability and disasters. Routledge London.

Bosschaart, A., Kuiper, W., van der Schee, J., \& Schoonenboom, J. (2013). The role of knowledge in students' flood-risk perception. Natural Hazards, 69(3), 1661-1680.

Brennan, M., O’Neill, E., Brereton, F., Dreoni, I., and Shahumyan, H. (2016). Exploring the spatial dimension of community-level flood risk perception: a cognitive mapping approach. Environmental Hazards, 15(4), 279-310. 
Brilly, M., and Polic, M. (2005). Public perception of flood risks, flood forecasting and mitigation. Natural Hazards and Earth System Science, 5(3), 345-355.

Burton, I., Kates, R. W., \& White, G. F. (1993). The environment as hazard. In The environment as hazard. The Guilford Press, New York.

Clerveaux, V., \& Spence, B. (2009). The Communication of Disaster Information and Knowledge to Children Using Game Technique: The Disaster Awareness Game (DAG). Int. J. Environ. Res, 3(2), 209-222.

Cooper, M. A., and Holle, R. L. (2012, September). Lightning safety campaigns-USA experience. In Lightning Protection (ICLP), 2012 International Conference on (pp. 1-7). IEEE.

Curtis, J. W., Shiau, E., Lowery, B., Sloane, D., Hennigan, K., \& Curtis, A. (2014). The prospects and problems of integrating sketch maps with geographic information systems to understand environmental perception: A case study of mapping youth fear in Los Angeles gang neighborhoods. Environment and Planning B: Planning and Design, 41(2), 251-271.

Cutter, S. L. (1993). Living with risk: the geography of technological hazards. Edward Arnold London.

Cutter, S. L., Boruff, B. J., \& Shirley, W. L. (2003). Social vulnerability to environmental hazards. Social science quarterly, 84(2), 242-261. 
Dewan, A., Hossain, M. F., Rahman, M. M., Yamane, Y., and Holle, R. L. (2017a). Recent lightning-related fatalities and injuries in Bangladesh. Weather, Climate, and Society, (2017).

Dewan, A., Ongee, E. T., Rahman, M. M., Mahmood, R., \& Yamane, Y. (2017b). Spatial and temporal analysis of a 17-year lightning climatology over Bangladesh with LIS data. Theoretical and Applied Climatology, 130(1), 1-16.

Dowdy, A. J. (2016). Seasonal forecasting of lightning and thunderstorm activity in tropical and temperate regions of the world. Scientific reports, 6, 20874.

FEMA. Lesson 1: Local Damage Assessment. (n.d.). Retrieved May 10, 2017, from https://emilms.fema.gov/IS559/lesson1/01_01_020print.htm.

Gaillard, J.C., 2010. Vulnerability, capacity and resilience: perspectives for climate and development policy. Journal of International Development, 22(2), pp.218-232.

Gaillard, J. C., \& Pangilinan, M. L. C. J. D. (2010). Participatory mapping for raising disaster risk awareness among the youth. Journal of Contingencies and Crisis Management, 18(3), 175-179.

Glade, T., Anderson, M. G., \& Crozier, M. J. (Eds.). (2006). Landslide hazard and risk. John Wiley \& Sons, West Sussex, England.

Gomes, C., Ahmed, M., Abeysinghe, K.R. and Hussain, F., (2006a). Lightning accidents and awareness in South Asia: experience in Sri Lanka and Bangladesh. In Proceedings of the 28th International Conference on Lightning Protection (ICLP), Kanasawa, Japan. 
Gomes, C., Kithil, R., \& Ahmed, M. (2006b). Developing a lightning awareness program model for third world based on American-South Asian experience. In Proceedings of the 28th international conference on lightning protection (ICLP), Kanasawa, Japan.

Gomes, C. and Kadir, M.Z.A., (2011). A theoretical approach to estimate the annual lightning hazards on human beings. Atmospheric Research, 101(3), pp.719-725.

Greening, L., \& Dollinger, S. J. (1992). Adolescents' perceptions of lightning and tornado risks. Journal of applied social psychology, 22(10), 755-762.

Grothmann, T., \& Reusswig, F. (2006). People at risk of flooding: why some residents take precautionary action while others do not. Natural Hazards, 38(1), 101-120.

Hagemeier-Klose, M., \& Wagner, K. (2009). Evaluation of flood hazard maps in print and web mapping services as information tools in flood risk communication. Natural Hazards \& Earth System Sciences, 9(2).

Haque, C.E. and Burton, I., 2005. Adaptation options strategies for hazards and vulnerability mitigation: an international perspective. In Mitigation of Natural Hazards and Disasters: International Perspectives (pp. 3-21). Springer Netherlands.

Holle, R.L., López, R.E., Howard, K.W., Vavrek, J. and Allsopp, J., (1995). Safety in the presence of lightning. In Seminars in neurology (Vol. 15, No. 04, pp. 375-380). (C) 1995 by Thieme Medical Publishers, Inc.

Holle, R.L., López, R.E. and Zimmermann, C., (1999). Updated recommendations for lightning safety-1998. Bulletin of the American Meteorological Society, 80(10), pp.2035-2041. 
Holle, R.L., (2008, April). Annual rates of lightning fatalities by country. In Preprints of the International Lightning Detection Conference, Arizona, USA (pp. 21-23).

Holle, R. L. (2016, April). Lightning-caused deaths and injuries related to agriculture. In Preprints of the 6th International Lightning Meteorology Conference (pp. 18-21).

Holle, R. L., \& Islam, A. K. M. S. (2017, January). Lightning fatalities in Bangladesh in May 2016. In Proceedings of the 8th Conference on the Meteorological Applications of Lightning Data. 2017 American Meteorological Society Annual Meeting Seattle, Washington (pp. 22-26).

Islam, S. (2016, June 22). Bangladesh declares lightning strikes a disaster as deaths surge. Retrieved May 09, 2017, from http://in.reuters.com/article/bangladesh-lightning-disasteridINKCN0Z81U4.

Izadkhah, Y.O. and Hosseini, M., 2005. Towards resilient communities in developing countries through education of children for disaster preparedness. International Journal of Emergency Management, 2(3), pp.138-148.

Jackson, E. L. (1981). Response to earthquake hazard the west coast of North America. Environment and Behavior, 13(4), 387-416.

Jayaratne, K.C. and Gomes, C., 2012, September. Public perceptions and lightning safety education in Sri Lanka. In Lightning Protection (ICLP), 2012 International Conference on (pp. 1-7). IEEE. 
Jensenius, J. S., \& Franklin, D. B. (2014). NOAA's efforts to reduce lightning fatalities through public education and awareness. In Preprints, 5th Intl. Lightning Meteorology Conference, Arizona, USA.

Jensenius Jr, J. S. (2016). NOAA's Lightning Safety Awareness Efforts-What We've Accomplished in 15 years. In $24^{\text {th }}$ International Lightning Detection Conference, California, USA.

Johnston, D. M., Bebbington Chin-Diew Lai, M. S., Houghton, B. F., \& Paton, D. (1999). Volcanic hazard perceptions: comparative shifts in knowledge and risk. Disaster Prevention and Management: An International Journal, 8(2), 118-126.

Kates, R. W. (1971). Natural hazard in human ecological perspective: hypotheses and models. Economic Geography, 47(3), 438-451.

Keul, A. G. (2012, September). Public lightning protection behavior in Central Europe-Mission accomplished? In Lightning Protection (ICLP), 2012 International Conference on (pp. 13). IEEE.

Kandalgaonkar, S. S., Tinmaker, M. I. R., Kulkarni, J. R., Nath, A. S. H. A., Kulkarni, M. K., \&Trimbake, H. K. (2005). Spatio-temporal variability of lightning activity over the Indian region. Journal of Geophysical Research: Atmospheres, 110(D11).

Kung, Y. W., \& Chen, S. H. (2012). Perception of earthquake risk in Taiwan: effects of gender and past earthquake experience. Risk Analysis, 32(9), 1535-1546.

Kunreuther, H. C., Slovic, P., \& MacGregor, D. (1996). Risk perception and trust: Challenges for facility siting. RISK: Health, Safety \& Environment, 7, pp.109-117. 
Lengyel, M.M., Brooks, H.E., Holle, R.L. and Cooper, M.A., (2005, January). Lightning casualties and their proximity to surrounding cloud-to-ground lightning. In American Meteorological Society annual meeting, California, USA.

López, R.E., Holle, R.L., Heitkamp, T.A., Boyson, M., Cherington, M. and Langford, K., 1993. The underreporting of lightning injuries and deaths in Colorado. Bulletin of the American Meteorological Society, 74(11), pp.2171-2178.

Mary, A. K., Gomes, A., Gomes, C., \& Ahmad, W. F. W. (2014, October). Lightning hazard mitigation in Uganda. In Lightning Protection (ICLP), 2014 International Conference. (pp. 1770-1779). IEEE.

Mercer, J. (2010). Disaster risk reduction or climate change adaptation: Are we reinventing the wheel? Journal of International Development, 22(2), pp.247-264.

Ramesh Kumar, P., \&Kamra, A. K. (2012). The spatiotemporal variability of lightning activity in the Himalayan foothills. Journal of Geophysical Research: Atmospheres, 117(D24).

Ranalkar, M. R., \&Chaudhari, H. S. (2009). Seasonal variation of lightning activity over the Indian subcontinent. Meteorology and atmospheric physics, 104(1-2), 125-134.

Roeder, W. P., Holle, R. L., Cooper, M. A., \& Hodanish, S. (2012, April). Lessons learned in communicating lightning safety effectively. In 4th international lightning meteorology conference, Broomfield, CO, Vaisala.

Roeder, W. P., Holle, R. L., Cooper, M.A., \&Hodanish, A. M. A. C. S. (2011). 1.2 Communicating Lightning Safety Effectively. In 91st American Meteorological Society Annual Meeting, Washington, USA. 
Samarajiva, R., 2005. Policy Commentary: Mobilizing information and communications technologies for effective disaster warning: lessons from the 2004 tsunami. New Media \& Society, 7(6), pp.731-747.

Schmidlin, T. W. (2009, December). Risk factors and social vulnerability. In Preprints of the international forum on tornado disaster risk reduction in Bangladesh, Dhaka, Bangladesh. Wind Engineering Research Center, Tokyo Polytechnic University.

Shklovski, I., Palen, L., \& Sutton, J. (2008, November). Finding community through information and communication technology in disaster response. In Proceedings of the 2008 ACM conference on Computer supported cooperative work (pp. 127-136). ACM.

Spengler, J. O., Connaughton, D. P., Zhang, J. J., \& Gibson, H. (2002). An Analysis of Lightning Safety Policies and Procedures in Florida's Municipal Recreation and Park Agencies. Journal of Park \& Recreation Administration, 20(3).

Takao, K., Motoyoshi, T., Sato, T., Fukuzondo, T., Seo, K., \& Ikeda, S., 2004. Factors determining residents' preparedness for floods in modern megalopolises: the case of the Tokai flood disaster in Japan. Journal of Risk Research, 7(7-8), 775-787.

UNISDR, T., 2004. Basic terms of disaster risk reduction. United Nations International Strategy for Disaster Reduction (UNISDR), Geneva.

Weinstein, N. D. (1989). Effects of personal experience on self-protective behavior. Psychological Bulletin, 105(1), 31-50.

White, G. F. (1945). Human adjustment to floods: a geographical approach to the flood problem in the United States (No. 29). University of Chicago. 
Wilhite, D. (2000). Drought as a natural hazard: Concepts and definitions. Routledge London.

Zhang, W., Meng, Q., Ma, M., \& Zhang, Y. (2011). Lightning casualties and damages in China from 1997 to 2009. Natural Hazards, 57(2), 465-476. 


\section{APPENDIX A}

Questionnaire for Survey

1. What is your age?
a) $19-40$
b) $41-60$
c) $61-80$
d) $80+$

2. What is your sex?
a) Male
b) Female

3. What is your highest level of education?
a) Primary
b) Secondary
c) Higher Secondary/college
d) Bachelor
e) Masters
f) Others

4. What is your occupation?

5. In which season does lightning occur in your locality/Village?
a) Pre-monsoon (January - April)
b) Monsoon (May-August)
c) Post-monsoon (September- December)
d) during the whole year

6. Do you think frequency of lightning changed in recent years?
a) Increased
b) Decreased
c) Unchanged

7. Do you think the lightning death rates changed in recent years?
a) Increased
b) Decreased
c) Unchanged

8. If you are outside and hear thunder, do you think you are in danger of being stuck by lightning? 

a) Yes
b) $\mathrm{No}$

9. Have you ever lost anything due to lightning strikes?
a) Yes
b) No

If yes, what kind of loss did you have?

10. Have you or someone you know ever been injured due to lightning strikes?
a) I have but no one I know has
b) I have and someone I know has
c) I have not but someone I know has
d) Neither I nor anyone I know has

11. Is there any siren, sign or announcement take place during lightning in your locality?
a) Yes
b) No

12. If you are working outside of your home, do you hear any sign, siren or announcement at your workplace while working?
a) Yes
b) No

13. How do you know lightning is nearby?
a) Media such as TV or Internet
b) I would hear it from others
c) I would notice environmental changes
d) None of the above

14. Do you regularly look at the weather forecasting on TV/ radio?
a) Daily
b) Once/Twice a week
c) Less than once a week
d) No, not at all

15. Have you ever got any lightning safety precaution/ training from your local authority?
a) Yes
b) No

If yes, what type of measures

16. Do you feel lightning is dangerous? 

a) Sometimes but not always
b) Rarely are they dangerous
c) Yes, very dangerous
d) No, they are not dangerous

17. Do you take any shelter if you hear sound of thunder suddenly?
a) Yes
b) No
c) I do not Care

18. If you hear thunder while you are outdoors, do you think that you are already in danger?
a) Yes, it is dangerous
b) No; it is not dangerous
c) I do not know

19. Which place is safe when a thunderstorm is in the area?
a) Inside house
b) Under tree
c) Inside car
d) Open area
e) Others

20. How long do you usually wait at a safe place after the last apparent lightning flash or thunder?
a) Less than 5 minutes
b) 6-15 minutes
c) 16-30 minutes
d) $30+$

21. Do you think that strike victims do not carry an electrical charge and may be safely touched?
a) Yes
b) No

22. Do you look at a weather forecast before planning to be outdoors?
a) Always
b) Sometimes
c) Never

23. How many people do you think are being killed each year due to lightning in Bangladesh?
a) Less than 100
b) $101-500$
c) $501-1000$
c) More than 1000

24. How do you know about the lightning deaths?
a) Newspaper
b) $\mathrm{TV}$
c) Radio
d) Internet
e) Other people

25. What do you think are activities that should not be done during lightning?

26. Why do you think people are struck by lightning? 
27. What kind of safety measures do you take when lightning occurs?

28. What do you think happens to a person struck by lightning? 


\section{APPENDIX B}

\section{Consent Form}

You are being invited to participate in a research study. This consent form will provide you with information on the research project, what you will need to do, and the associated risks and benefits of the research. Your participation is voluntary. Please read this form carefully. It is important that you ask questions and fully understand the research in order to make an informed decision. You will receive a copy of this document to take with you.

The purpose of this study is to look at the people's perception about lightning hazard in Bangladesh. This study will provide a broader and critical understanding of why a large number of people in Bangladesh are being killed in Bangladesh each year. It is also going to address why the number of deaths due to lightning in Bangladesh is higher than the deaths in developed countries. I hope that this study will be helpful for the development of mitigation strategies and decision making ultimately will play a role in minimizing the loss of lives and property. This study is going to be conducted as part of the master's thesis at the department of geography at Kent State University.

I am here to ask you some questions about your perception of lightning. Most of the questions will be closed ended questions and some of the questions will be open-ended questions so that you can provide your opinion. You will read and answer the questions if they do not want to write the answer I will write those answer. If you are confused about any questions, let me know I will describe you. It will take 10-15 minutes to answer all the questions. 
This research may not benefit you directly, however, your participation in this study will help us better understand the consequences of lightning hazard in Bangladesh. In broader sense, this study will be helpful for the government to initiate and development of mitigation strategies and improve awareness among the people in Bangladesh. There are no anticipated risks beyond those encountered in everyday life.

Your study related information will be kept confidential within the limits of the law. Our record of your responses will not have your name on it, or any other way of identifying you. Only the researchers will have access to your responses. Research participants will not be identified in any publication or presentation of research results; only aggregate data will be used.

Taking part in this research study is entirely up to you. You may choose not to participate or you may discontinue your participation at any time without penalty. You may skip any question that you do not want to answer.

If you have any questions about this study, you may contact Prof. Thomas Schmidlin at 330-672-3227 or Md Sariful Islam at 330-990-8385 / 01745545333 at any time. The Kent State University Institutional Review Board has approved this project. If you have any questions about your rights as a research participant or complaints about the research, you may call the IRB at 330.672.2704. 